\title{
Article \\ Cationic Dye Degradation and Real Textile Wastewater Treatment by Heterogeneous Photo-Fenton, Using a Novel Natural Catalyst
}

\author{
Sirine Ben Ayed ${ }^{1}\left(\mathbb{D}\right.$, Mohammad Azam $^{2}$, Saud I. Al-Resayes ${ }^{2}$, Fadhila Ayari ${ }^{1, *}$ and Luigi Rizzo $^{3, *(\mathbb{D})}$ \\ 1 Department of Chemistry, Faculty of Sciences of Bizerte, Laboratory of Applications of Chemistry to \\ Resources and Natural Substances and to the Environment (LACReSNE), Carthage University, \\ Zarzouna 7021, Tunisia; sirinebenayed19@gmail.com \\ 2 Department of Chemistry, King Saud University, P.O. Box 2454, Riyadh 1145, Saudi Arabia; \\ mhashim@ksu.edu.sa (M.A.); sresayes@ksu.edu.sa (S.I.A.-R.) \\ 3 Water Science and Technology Group (WaSTe), Department of Civil Engineering, University of Salerno, \\ Via Giovanni Paolo II 132, 84084 Fisciano, Italy \\ * Correspondence: fadhilaayari@yahoo.fr (F.A.); 1.rizzo@unisa.it (L.R.)
}

Citation: Ben Ayed, S.; Azam, M.; Al-Resayes, S.I.; Ayari, F.; Rizzo, L. Cationic Dye Degradation and Real Textile Wastewater Treatment by Heterogeneous Photo-Fenton, Using a Novel Natural Catalyst. Catalysts 2021, 11, 1358. https://doi.org/ $10.3390 /$ catal11111358

Academic Editor: Enric Brillas

Received: 27 September 2021

Accepted: 9 November 2021

Published: 12 November 2021

Publisher's Note: MDPI stays neutral with regard to jurisdictional claims in published maps and institutional affiliations.

Copyright: (c) 2021 by the authors. Licensee MDPI, Basel, Switzerland. This article is an open access article distributed under the terms and conditions of the Creative Commons Attribution (CC BY) license (https:// creativecommons.org/licenses/by/ $4.0 /)$.
Abstract: A photo-Fenton process using a local iron oxide as a natural catalyst was compared to Fenton and $\mathrm{UV} / \mathrm{H}_{2} \mathrm{O}_{2}$ advanced oxidation processes for degrading crystal violet $(\mathrm{CV})$ dye in aqueous solutions. The catalyst was characterized by transmission electron microscopy (TEM), energy dispersive X-ray microanalysis (EDX), Fourier transform infrared spectroscopy (FT-IR), Raman spectrum, X-ray diffraction (XRD), UV-vis spectroscopy, and Brunauer-Emmett-Teller (BET) analysis. The optical properties proved that the catalyst represents a good candidate for photocatalytic activity. The impact of different parameters (catalyst dose, initial CV concentration, initial $\mathrm{H}_{2} \mathrm{O}_{2}$ concentration, $\mathrm{pH}$ ) on the photo-Fenton efficiency was evaluated. A photo-Fenton process operated

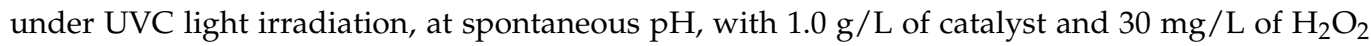
was the most effective process, resulting in $98 \% \mathrm{CV}$ dye removal within $3 \mathrm{~h}$. LC-MS and ionchromatography techniques were used to identify demethylated organic intermediates during the process. Furthermore, a regeneration study of the catalyst showed its stability and reusability (after three treatment cycles, CV dye degradation decreased from $94 \%$ to $83 \%$ ). Finally, the photo-Fenton process was tested in the treatment of real textile wastewater, and the effluent was found to be in compliance with standards for industrial wastewater disposal into sewerage.

Keywords: advanced oxidation processes; crystal violet dye; heterogeneous catalyst; iron oxide; regeneration; real wastewater

\section{Introduction}

Dyes are organic compounds often utilized in the paper, plastic, pigment, cosmetic, and textile industries [1,2]. Textile factories produce wastewater characterized by a very low biodegradability, high amounts of surfactants, high chemical oxygen demand (COD), toxicity, highly fluctuating temperature and $\mathrm{pH}$, and a strong color $[3,4]$. These textile effluents represent a serious problem for the environment, and even their degradation products may be toxic, thus threatening public health and aquatic organisms [5].

Several methods have been tested to remove dyes from water, including membrane separation [6], conventional coagulation/flocculation [7] and adsorption [8]. Unfortunately, these methods can only transfer pollutants from liquid to solid phase. Moreover, several dyes are not biodegradable, making a biological process alone not a suitable solution for textile wastewater treatment. Advanced oxidation processes (AOPs) are a possible solution for degrading bio-refractory pollutants. These processes promote the formation of highly reactive and non-selective oxidants species, such as hydroxyl radicals $\left({ }^{\bullet} \mathrm{OH}\right)$ that can degrade and mineralize recalcitrant compounds and eventually obtain non-toxic inorganic 
molecules, such as $\mathrm{CO}_{2}$ and $\mathrm{H}_{2} \mathrm{O}$ [9]. Among them, Fenton reaction (iron salts + hydrogen peroxide) based processes are particularly effective for industrial wastewater treatment, to improve biodegradability before the biological process [10]. Unfortunately, Fenton-based processes are effective at acidic $\mathrm{pH}$, because iron starts to precipitate at $\mathrm{pH}>3$, thus resulting in an environmental problem (sludge production) and increased treatment costs, due to wastewater acidification and the subsequent $\mathrm{pH}$ neutralization before the biological process [11]. In order to overcome these drawbacks, different approaches have been investigated in recent years. One approach includes chelating agent addition to promote the formation of complexes with metal species, making (photo) Fenton process effective, even at neutral $\mathrm{pH}[12,13]$. However, while effective in tertiary treatment of urban wastewater, the addition of chelating agents can be quite problematic when applied to remove organic pollutants in high concentrations, such as in industrial wastewater treatment [14]. Another approach has been established with the utilization of solid phase (photo) catalysts (heterogeneous photo-Fenton). In the photocatalytic degradation of dyes, many iron oxides have been investigated in previous studies, regarding their impressive photocatalytic activity, structural stability, and narrow band gap, such as magnetite, goethite, and hematite [15]. However, most of the works available in the scientific literature only investigated the effect of the process on dye aqueous solutions [16], not taking into account the interference of other substances (such as dissolved organic matter), typically occurring in real wastewater. Accordingly, investigations on real wastewater are highly advisable, to evaluate the effect of the processes under realistic conditions and to speed up their possible applications at industrial scale. Moreover, to make the process sustainable and economically affordable, potentially reusable, stable, and cheap catalysts are desirable and worthy of investigation.

In this study, a heterogeneous photo-Fenton process using a new natural iron oxide as catalyst was evaluated for the degradation of crystal violet (CV) dye and compared to Fenton (iron oxide $+\mathrm{H}_{2} \mathrm{O}_{2}$ ) and $\mathrm{UV} / \mathrm{H}_{2} \mathrm{O}_{2}$ processes for the first time. $\mathrm{CV}$ was used as model dye because it is one of the most widespread and recalcitrant dye molecules, which has toxic effects in the environment [17] and it is a potent carcinogen and clastogene that boosts the growth of tumors in some species of fish [18]. Control tests with photolysis (UV) and oxidation $\left(\mathrm{H}_{2} \mathrm{O}_{2}\right)$ were also carried out. The catalyst was characterized by transmission electron microscopy (TEM), energy dispersive X-ray microanalysis (EDX), Fourier transform infrared spectroscopy (FT-IR), X-ray diffraction (XRD), Raman spectroscopy, UV-vis diffuse reflectance spectroscopy (DRS), and Brunauer-Emmett-Teller (BET) and Barrett-Joyner-Halenda (BJH) analyses. AOPs can lead to the formation of oxidation intermediates that can be even more toxic than the parent substances [19], accordingly CV intermediates were also analyzed by LC/MS and ion-chromatography. Catalyst reusability tests were also carried out. Finally, the photo-Fenton process with this new catalyst was also investigated in the treatment of real textile wastewater.

\section{Results and Discussion}

\subsection{Catalyst Characterization}

\subsubsection{XRD, Raman, and FT-IR Analysis}

XRD characterization of the catalyst (Figure 1a) indicates peaks relevant to hematite $\left(\mathrm{Fe}_{2} \mathrm{O}_{3}\right)$ at 20 34, 40.2 and $~ 64$ [20], magnetite $\left(\mathrm{Fe}_{3} \mathrm{O}_{4}\right)$ at 20 21.5, 30, 37 and 61.5 [21], goethite $(\mathrm{FeOOH})$ at $2 \theta \sim 15.1, \sim 24.5, \sim 35, \sim 35.70, \sim 41.4, \sim 50.2, \sim 53.4$ and $\sim 59.2$ [22], Kaolinite $(2 \theta \sim 9)$ and quartz (20 26).

IR spectrum of the catalyst (Figure $1 \mathrm{~b}$ ) indicates two absorption bands at 480 and $560 \mathrm{~cm}^{-1}$, which represent the vibration bands of $\mathrm{Si}-\mathrm{O}$ and $\mathrm{O}-\mathrm{Fe}-\mathrm{O}$ functional groups, respectively [23]. Both bands at 890 and $784 \mathrm{~cm}^{-1}$ are related to the vibrations in and out of the plane of $\mathrm{O}-\mathrm{H}$ bending bands in goethite phase [24,25]. Bands at 1041 and $1642 \mathrm{~cm}^{-1}$ are assigned to the asymmetric stretching vibration of $\mathrm{Fe}-\mathrm{O}-\mathrm{Si}$ and $\mathrm{O}-\mathrm{H}$, respectively. The band at $1451 \mathrm{~cm}^{-1}$ is attributed to asymmetric stretching vibration of $\mathrm{C}=\mathrm{O}$ [25]. Finally, the band at $3388 \mathrm{~cm}^{-1}$ is related to $\mathrm{O}-\mathrm{H}$ stretching vibration in hydroxyl groups [26]. 

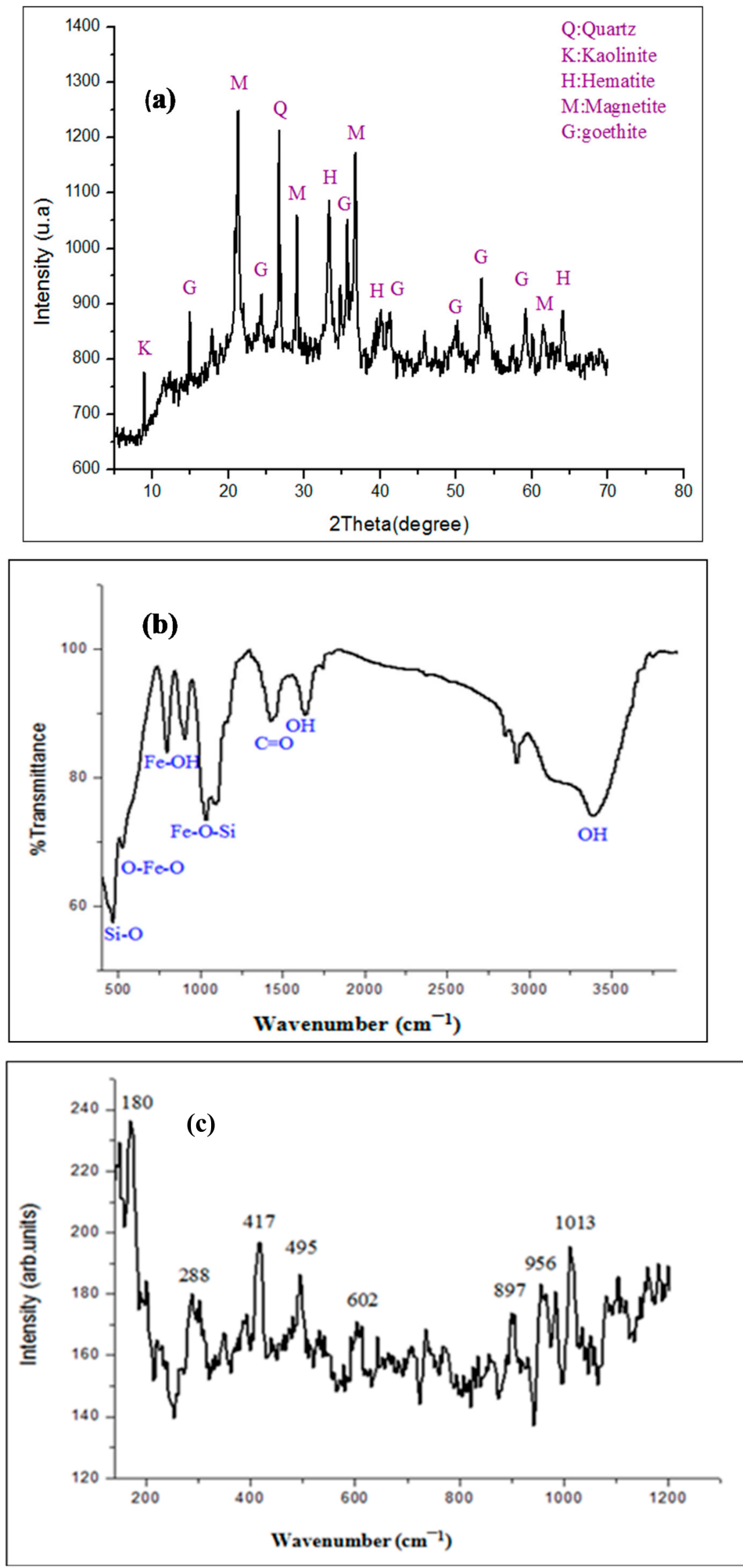

Figure 1. XRD pattern (a), IR spectrum (b), and Raman spectrum (c) of the catalyst.

Raman spectrum of the catalyst (Figure 1c) in the wavelength range of $150-1200 \mathrm{~cm}^{-1}$ is characterized by many peaks. Bands at $180 \mathrm{~cm}^{-1}$ and $288 \mathrm{~cm}^{-1}$ are attributed to hematite phase in the natural iron oxide [27]. Magnetite phase is mostly identified by the existence of a band at $602 \mathrm{~cm}^{-1}$ [28]. Bands at 417 and $495 \mathrm{~cm}^{-1}$ can be assigned to goethite phase, as reported in previous studies $[29,30]$. The two bands at 956 and $1013 \mathrm{~cm}^{-1}$ are associated with Siderite phase [27]. 


\subsubsection{TEM-EDX and DRS Analyses}

A TEM micrograph of the catalyst (Figure $2 a, b$ ) shows rod shaped structures with various thicknesses and lengths, according to previous works [31]. A good dispersion of iron oxide rods is expected to enhance the photocatalytic activity. EDX analysis (Figure 2c) indicates the existence of several elements such as $\mathrm{Fe}(\mathrm{wt} \%=63.6), \mathrm{Si}(\mathrm{wt} \%=30.2), \mathrm{Al}(\mathrm{wt} \%$ =3.2), As ( $w t \%=1.7)$, and $\mathrm{Mg}(\mathrm{wt} \%=1.3)$, confirming the results of the XRD and Raman analyses. The significant amount of Fe proves that this material can be successfully used as a catalyst in Fenton and photo-Fenton processes.

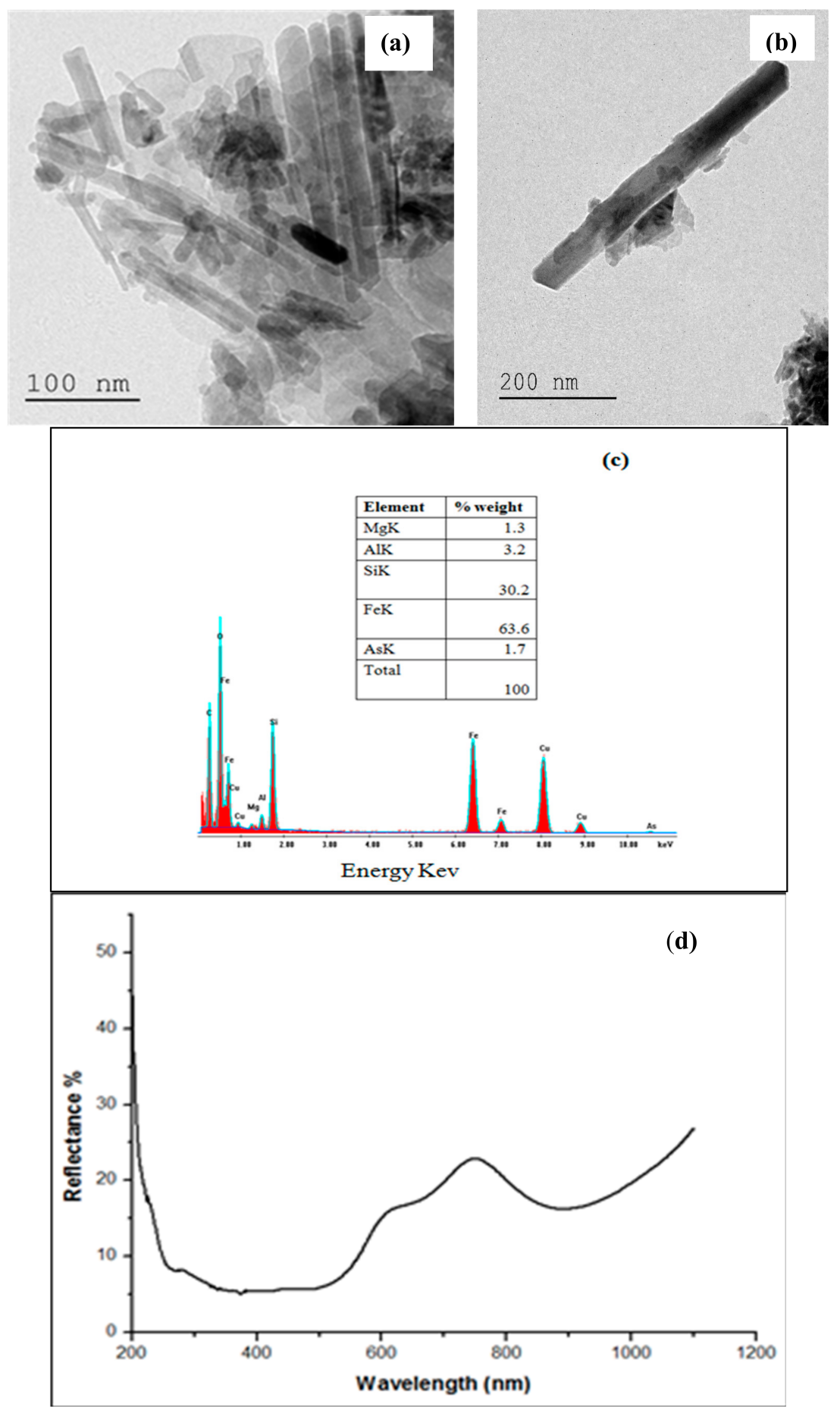

Figure 2. TEM micrographs at different scales: (a) $100 \mathrm{~nm}$ and (b) $200 \mathrm{~nm}$; (c) EDX spectrum; (d) DRS of the catalyst. 
DRS spectrum (Figure 2d) reveal three absorption peaks at $\lambda=280 \mathrm{~nm}, 610 \mathrm{~nm}$ and $750 \mathrm{~nm}$, respectively, suggesting the good optical response of the catalyst under UV and visible light regions for photocatalytic activity.

\subsubsection{BET and BJH Analyses}

According to IUPAC classification, the BET adsorption isotherm of the catalyst (Figure 3) displays a curve of type IV with a hysteresis loop [32].

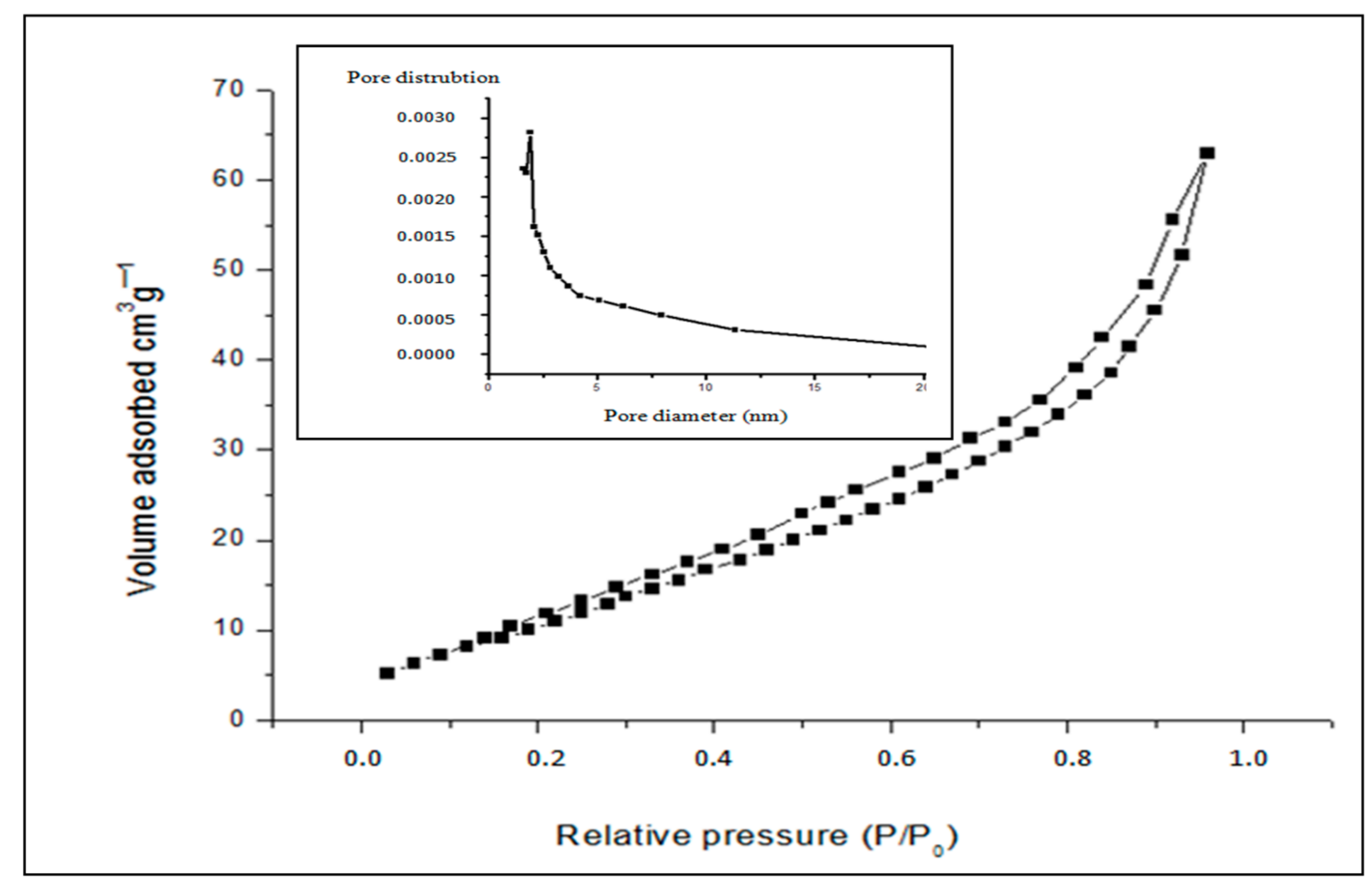

Figure 3. $\mathrm{N}_{2}$ Adsorption/desorption isotherm of natural iron oxide.

A BJH method using desorption isotherms allowed quantifying the iron oxide total pore volume as $0.1 \mathrm{~cm}^{3} / \mathrm{g}$ (Figure 3, Table 1). Specific surface area of the catalyst was estimated as $45.86 \mathrm{~m}^{2} \mathrm{~g}^{-1}$ using BET method (Table 1). The mesoporous surface area and volume values as obtained by BJH method are also displayed in Table 1.

Table 1. Textural properties of the catalyst.

\begin{tabular}{ccccc}
\hline $\mathrm{S}_{\text {BET }}\left(\mathrm{m}^{2} / \mathrm{g}\right)$ & $\mathrm{S}_{\mathrm{BJH} / \mathrm{mesp}}\left(\mathrm{m}^{2} / \mathrm{g}\right)$ & $\mathrm{V}_{\mathrm{BJH} / \mathrm{mesp}}\left(\mathrm{cm}^{2} / \mathrm{g}\right)$ & $\mathrm{V}_{\text {ads }}\left(\mathrm{cm}^{\mathbf{3} / \mathrm{g})}\right.$ & $\mathrm{D}\left(\mathrm{A}^{\circ}\right)$ \\
\hline 45.86 & 44.17 & 0.092 & 0.1 & 20 \\
\hline
\end{tabular}

$\mathrm{S}_{\mathrm{BET}}$ : $\mathrm{BET}$ surface area; $\mathrm{S}_{\mathrm{BJH} / \text { mesp }}$ : mesopore surface area; $\mathrm{V}_{\mathrm{BJH} / \mathrm{msp}}$ : mesopore volume; $\mathrm{V}_{\mathrm{ads}}$ : volume of $\mathrm{N}_{2}$ adsorbed at $\mathrm{P} / \mathrm{P}_{0}=0.98$;

$\mathrm{D}$ : average pore diameter.

Notably, owing to a larger surface area, more catalytically active sites are available and can improve the photocatalytic activity [33].

The pore size distribution (inset in Figure 3) supports the mesoporous framework of the catalyst, according to IUPAC, with an average pore size of $2 \mathrm{~nm}$ (peak at pore diameter $=2 \mathrm{~nm})[34]$.

\subsection{Degradation of CV Dye in Aqueous Solution by AOPs}

\subsubsection{Dark Adsorption Test}

Dark tests with the catalyst were carried to evaluate the adsorption process contribution to CV dye removal, as well as the time needed to achieve adsorption-desorption equilibrium. The maximum adsorption of $\mathrm{CV}$ dye by the catalyst was as high as $70 \%$ and 
the adsorption-desorption equilibrium was reached within an hour (Figure 4), which is consistent with a relevant previous adsorption study [35].

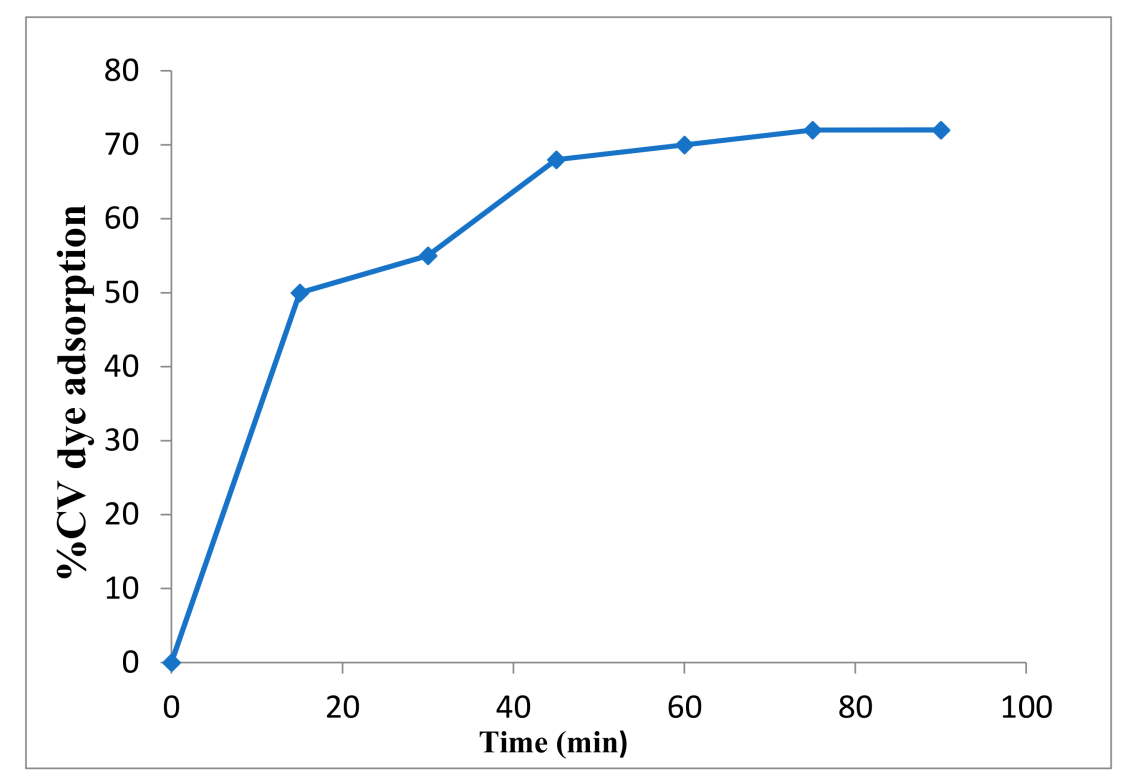

Figure 4. Kinetic of $\mathrm{CV}$ dye adsorption onto natural iron oxide $\left((\mathrm{CV})=10 \mathrm{mgL}^{-1}, \mathrm{~m}_{\text {cat }}=0.1 \mathrm{~g}\right.$, $\left.\mathrm{T}=25^{\circ} \mathrm{C}\right)$.

\subsubsection{Photo-Fenton Experiments}

The photo-Fenton process was compared to Fenton and $\mathrm{H}_{2} \mathrm{O}_{2} / \mathrm{UV}$ processes. Control tests by photolysis and $\mathrm{H}_{2} \mathrm{O}_{2}$, as standalone processes, were also carried out under fixed initial conditions ( $1.0 \mathrm{~g}$ of catalyst/ $\mathrm{L}, 30 \mathrm{mg} \mathrm{H}_{2} \mathrm{O}_{2} / \mathrm{L}$, room temperature, neutral $\mathrm{pH}$ (6.7)). The results clearly show that photo-Fenton was the most effective among all the tested processes, achieving $94 \%$ removal efficiency after $180 \mathrm{~min}$ (Figure 5). The contributions to $\mathrm{CV}$ degradation by photolysis and direct oxidation with $\mathrm{H}_{2} \mathrm{O}_{2}$ were quite poor $(6 \%$ and $18 \%$ after $180 \mathrm{~min}$, respectively). The $\mathrm{UV} / \mathrm{H}_{2} \mathrm{O}_{2}$ advanced oxidation process was more efficient than UV and $\mathrm{H}_{2} \mathrm{O}_{2}$ separately, but still poorly effective (only 39\% after 180 min treatment) compared to the Fenton and photo-Fenton processes, consistent with a previous work [36]. The final efficiency of the Fenton process ( $85 \%$ ) was comparable with the photo-Fenton, but the degradation rate was slower, making photo-Fenton potentially more attractive, due to the reduced volume necessary to achieve a high degradation rate.

\subsubsection{Dye Degradation by Photo-Fenton Process: Effect of Different Parameters}

\section{Effect of the Initial Pollutant Concentration}

The removal efficiency of CV by photo-Fenton decreased from $99 \%$ to $80 \%$ by increasing the initial dye concentration from 5 to $20 \mathrm{mg} / \mathrm{L}$ (Figure 6a). These results can be explained by the fact that higher concentrations of the pollutant increased the pollutant/radicals ratio, as well as decreasing the penetration of photons, due to the darker color of the aqueous solution [37].

\section{Effect of Catalyst Dose}

The influence of the catalyst mass on dye degradation via photo-Fenton process was also investigated by varying the catalyst dose from 0.5 to $2.0 \mathrm{~g} / \mathrm{L}$ and keeping constant the other operating parameters. The $\mathrm{CV}$ removal efficiency increased as the catalyst dose was augmented from $0.5 \mathrm{~g} / \mathrm{L}$ to $1.0 \mathrm{~g} / \mathrm{L}$, and decreased when the catalyst dose was further increased up to $2.0 \mathrm{~g} / \mathrm{L}$ (Figure $6 \mathrm{~b}$ ). This behavior is typical for a heterogeneous photocatalytic process. The efficiency improved as the catalyst loading was increased up to achieving a maximum pollutant removal; then started to decrease for further additions 
of the catalyst, due to the increased opacity of the aqueous solution, which prevents the penetration of photons, thus reducing the radical yield [38]. Accordingly, the optimum catalyst dose in this study was found to be $1.0 \mathrm{~g} / \mathrm{L}$.

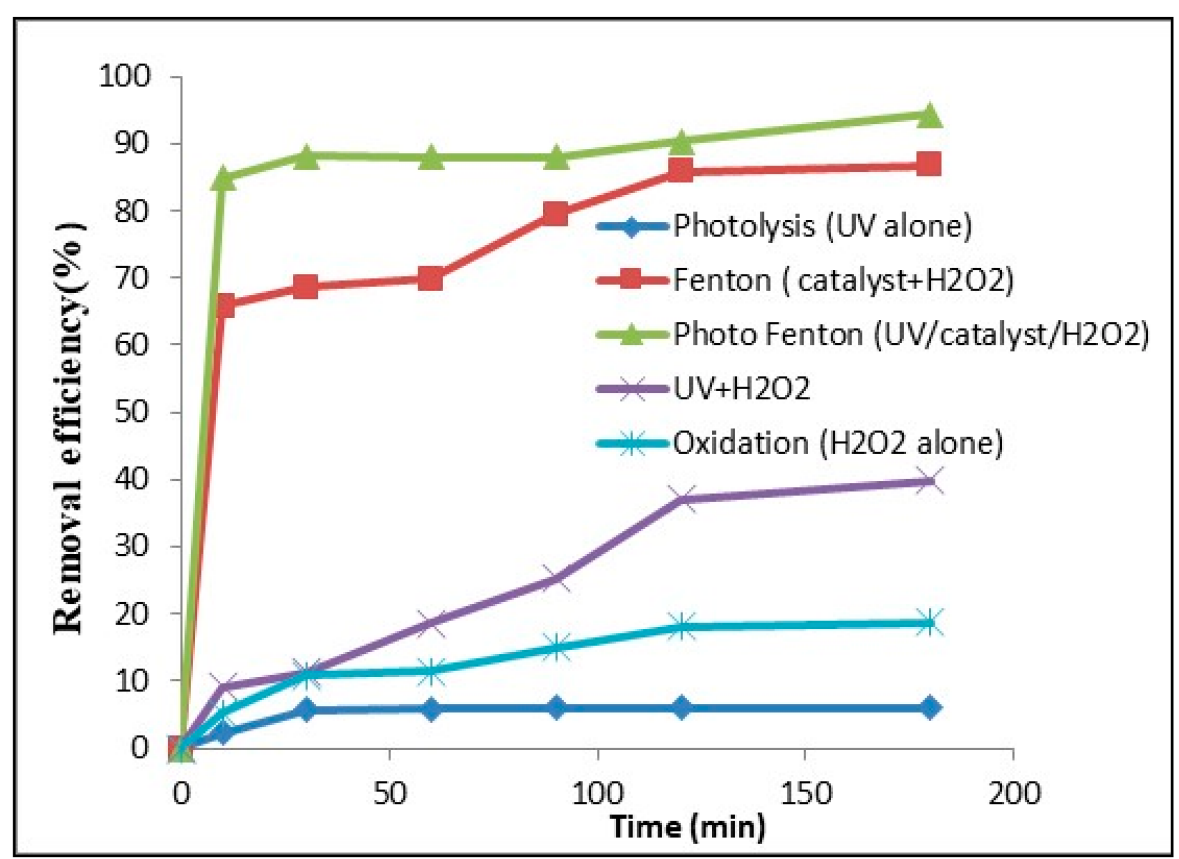

Figure 5. CV dye removal under different tested processes.
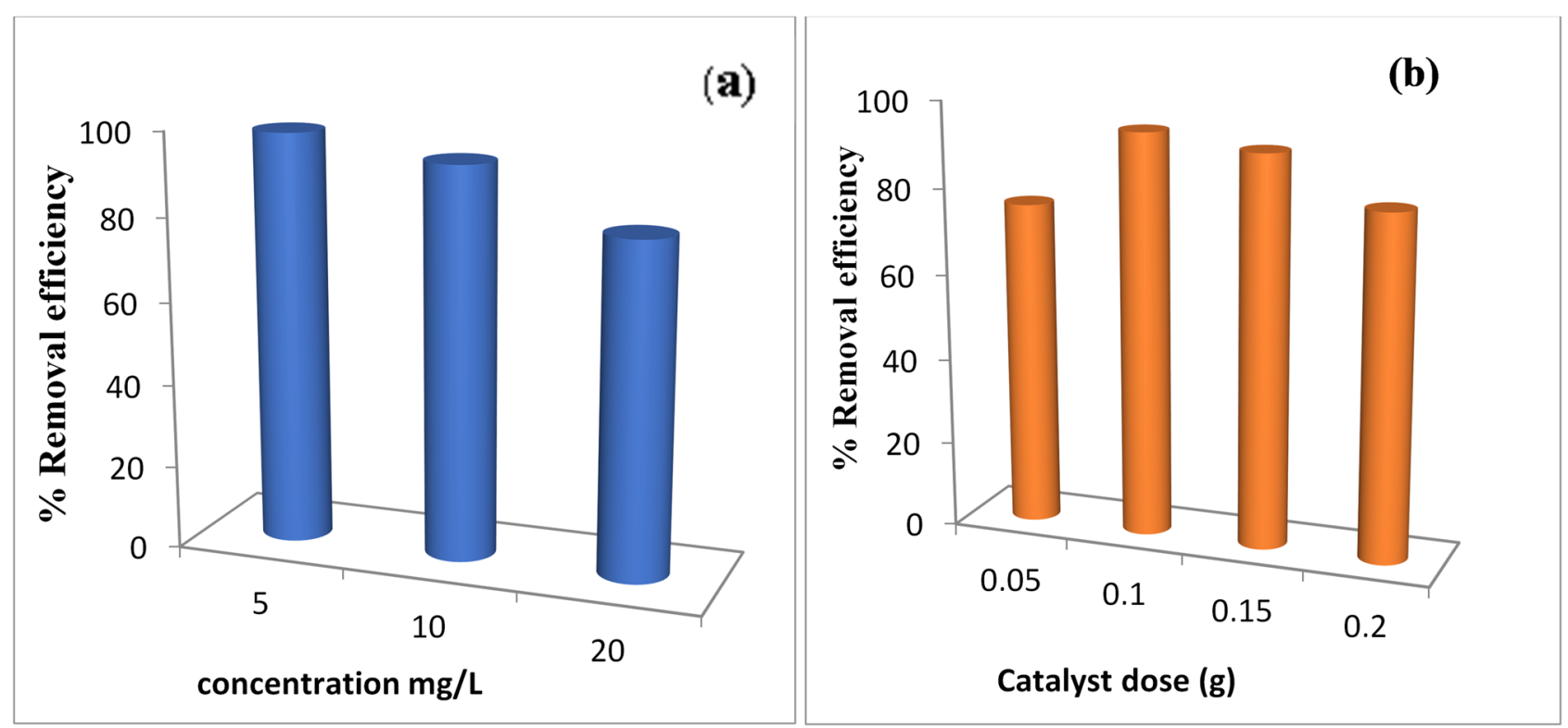

Figure 6. Cont. 


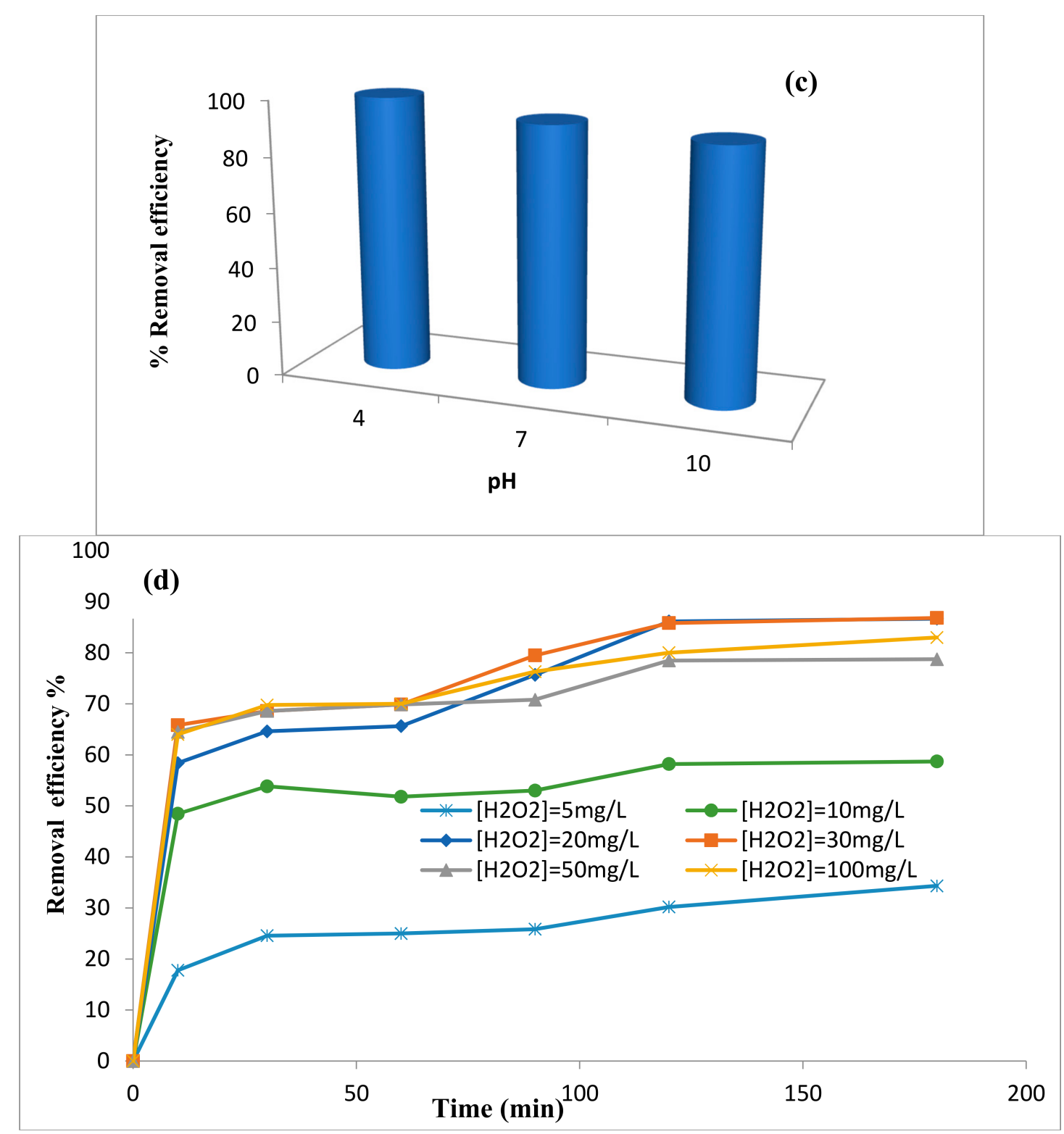

Figure 6. Effect of pollutant concentration (a), catalyst dose (b), $\mathrm{pH}$ of $\mathrm{CV}$ solution (c), and oxidant concentration (d) on the CV dye degradation by photo-Fenton.

Effect of $\mathrm{pH}$

It is well-known that in homogenous processes, $\mathrm{pH}$ can drastically affect the (photo) Fenton efficiency, with $\mathrm{pH}<3$ being the optimum condition. However, the main expected advantage in using iron oxide as a catalyst is related to the possibility of effectively operate the process under neutral $\mathrm{pH}$ conditions [39]. Due to the $\mathrm{Fe}(\mathrm{II}) / \mathrm{Fe}(\mathrm{III})$ species immobilized on the surface of the solid, an efficient redox system with $\mathrm{H}_{2} \mathrm{O}_{2}$ in a wider $\mathrm{pH}$ range is expected. Three different $\mathrm{pH}$ conditions were investigated, and the photo-Fenton process was found to be minimally affected by $\mathrm{pH}$, with $100 \%, 94 \%$, and $91 \%$ removals of $\mathrm{CV}$ observed at $\mathrm{pH} 4,7$ and 10, respectively (Figure 6c).

Effect of $\mathrm{H}_{2} \mathrm{O}_{2}$ Concentration

In photo-Fenton process, the catalyst dose, $\mathrm{H}_{2} \mathrm{O}_{2}$ concentration and their ratio are among the most relevant parameters, because they affect the active radical concentration yield. To evaluate the influence of hydrogen peroxide on the $\mathrm{CV}$ dye degradation, its initial concentration was varied from $5 \mathrm{mg} / \mathrm{L}$ to $100 \mathrm{mg} / \mathrm{L}$. When the $\mathrm{H}_{2} \mathrm{O}_{2}$ concentration was 
increased from $5 \mathrm{mg} / \mathrm{L}$ to $30 \mathrm{mg} / \mathrm{L}$, the removal efficiency drastically increased from $34 \%$ to $86 \%$ (Figure $6 \mathrm{~d}$ ). This result can be explained by the higher radical production rate, due to the increased oxidant dose. However, further increases in $\mathrm{H}_{2} \mathrm{O}_{2}$ concentration (from $30 \mathrm{mg} / \mathrm{L}$ to $100 \mathrm{mg} / \mathrm{L}$ ) resulted in a decreased removal efficiency (from $86 \%$ to $78 \%$ ). This, only apparently, inconsistent result can be actually explained by the $\mathrm{OH}$ radical scavenging activity due to hydrogen peroxide excess (Equations (1) and (2)) [40]:

$$
\begin{gathered}
\mathrm{H}_{2} \mathrm{O}_{2}+\mathrm{HO}^{\bullet} \rightarrow \mathrm{H}_{2} \mathrm{O}+\mathrm{HO}^{\bullet} \\
\mathrm{HO}_{2} \\
\mathrm{H}_{2}+\mathrm{HO}^{\bullet} \rightarrow \mathrm{H}_{2} \mathrm{O}+\mathrm{O}_{2}
\end{gathered}
$$

Goethite, hematite and magnetite are among the common forms of iron oxide that can catalyze $\mathrm{H}_{2} \mathrm{O}_{2}$ to generate radicals and degrade organic pollutants [41]. In particular, some authors observed a similar decomposition of $\mathrm{H}_{2} \mathrm{O}_{2}$ catalyzed by goethite and hematite when normalized to the surface area [42,43]. Several mechanisms have been proposed to explain the degradation kinetics of pollutants through iron oxide catalyzed reactions in the heterogeneous Fenton process. According to the main one, ${ }^{\bullet} \mathrm{OH}$ is an intermediate primarily responsible for the degradation of the target organic pollutant [44]. Due to the low concentration of dissolved iron, Lin and Gurol [45] proposed a mechanism for a goethite-catalyzed Fenton-like reaction, where diffusion and adsorption of $\mathrm{H}_{2} \mathrm{O}_{2}$ to the oxide surface takes place before the decomposition of $\mathrm{H}_{2} \mathrm{O}_{2}$ on the surface of goethite. An enzymatic-like activity similar to peroxidases has also been proposed as a possible mechanism for the degradation of pollutants by magnetite catalyzed Fenton process, through the intermediates generated between $\mathrm{H}_{2} \mathrm{O}_{2}$ and magnetite [46,47].

In conclusion, $30 \mathrm{mg} / \mathrm{L}$ was the optimum $\mathrm{H}_{2} \mathrm{O}_{2}$ concentration to degrade $\mathrm{CV}$ dye by photo-Fenton process under the investigated conditions.

The residual concentration of $\mathrm{H}_{2} \mathrm{O}_{2}$ during the process was also monitored and an almost total consumption was observed after a three hour treatment (Figure 7).

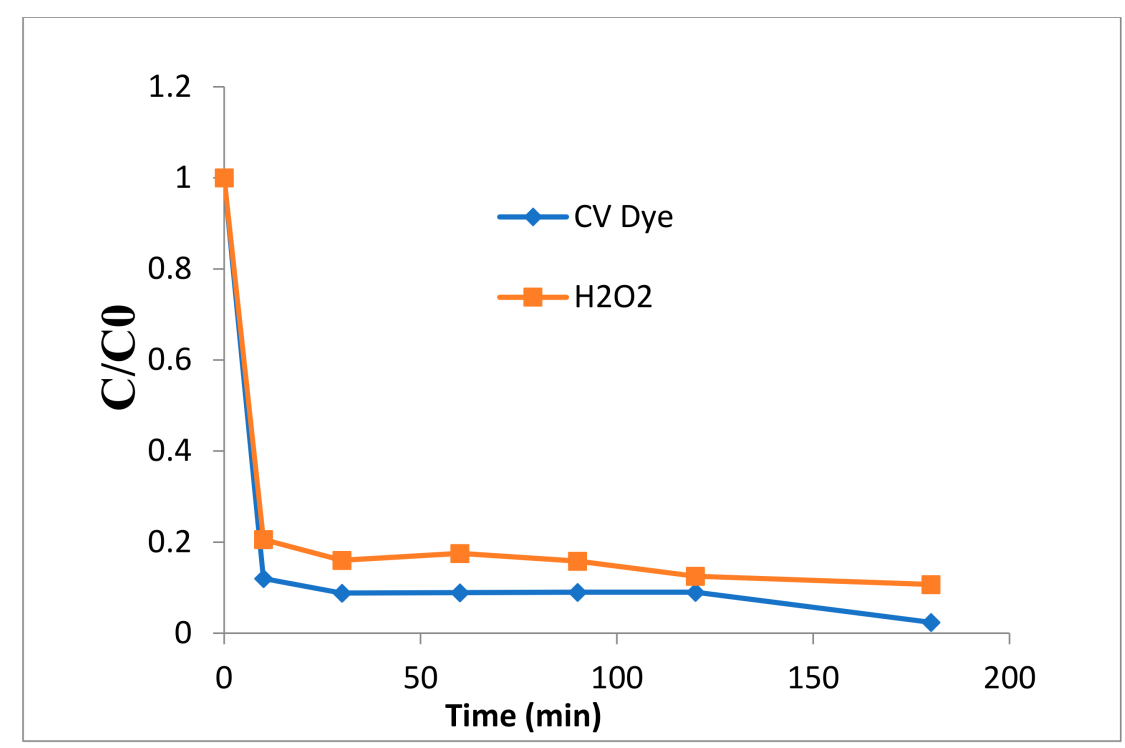

Figure 7. Degradation of $\mathrm{CV}$ dye and $\mathrm{H}_{2} \mathrm{O}_{2}$ consumption during the photo-Fenton process under optimum conditions $\left((\mathrm{CV})=10 \mathrm{mg} / \mathrm{L},\left(\mathrm{H}_{2} \mathrm{O}_{2}\right)=30 \mathrm{mg} / \mathrm{L}\right.$ catalyst concentration $\left.1.0 \mathrm{~g} / \mathrm{L}\right)$.

If we compare the results achieved under optimum conditions with those available in the scientific literature for other iron based catalysts, we can see that it is very competitive in terms of process efficiency (Table 2). 
Table 2. Comparison of natural iron oxide with different photocatalysts for CV dye degradation by photo-Fenton process.

\begin{tabular}{|c|c|c|c|}
\hline Catalyst & Operating Conditions & Degradation Percentage & Reference \\
\hline Fe-Montmorillonite & $\begin{array}{c}\text { Dosage: } 0.15 \mathrm{~g} / \mathrm{L} ;\left(\mathrm{H}_{2} \mathrm{O}_{2}\right)=50 \mathrm{mM} ;(\mathrm{CV})=0.06 \mathrm{mM} \text {, } \\
\text { visible light irradiation }\end{array}$ & $90 \%$ & [48] \\
\hline $\mathrm{K}_{2} \mathrm{Fe}_{4} \mathrm{O}_{7}$ & $\begin{array}{c}\text { Dosage: } 0.03 \mathrm{~g} / \mathrm{L} ;\left(\mathrm{H}_{2} \mathrm{O}_{2}\right)=5 \mathrm{mM} ;(\mathrm{CV})=20 \mathrm{mg} / \mathrm{L} \\
\text { visible light irradiation }\end{array}$ & $92 \%$ & [5] \\
\hline $\begin{array}{c}\mathrm{Fe}_{3} \mathrm{O}_{4-} \\
\text { polydopamine-bentonite } \\
\text { composite }\end{array}$ & $\begin{array}{c}\text { Dosage: } 0.03 \mathrm{~g} / \mathrm{L} ;\left(\mathrm{H}_{2} \mathrm{O}_{2}\right)=1 \mathrm{mM} ;(\mathrm{CV})=20 \mathrm{mg} / \mathrm{L} ; \\
\text { UV light irradiation }\end{array}$ & $93 \%$ & [49] \\
\hline Natural iron oxide & $\begin{array}{c}\text { Dosage: } 1 \mathrm{~g} / \mathrm{L} ;\left(\mathrm{H}_{2} \mathrm{O}_{2}\right)=30 \mathrm{mg} / \mathrm{L} ;(\mathrm{CV})=10 \mathrm{mg} / \mathrm{L} \\
\text { UVC light irradiation }\end{array}$ & $98 \%$ & This work \\
\hline
\end{tabular}

\subsection{Kinetic Study and Oxidation Intermediates Characterization}

\subsubsection{Kinetic Study}

The photocatalytic degradation of organic pollutants is typically well-described using a pseudo-first-order (PFO) model, used herein to evaluate the kinetic degradation of CV dye by photo-Fenton reaction through the following equation:

$$
\ln \left(\frac{C_{0}}{C_{t}}\right)=k \cdot t
$$

$t$ ( $\mathrm{min})$ is the irradiation time, $C_{0}$ and $C_{t}$ are the initial and time $t$ concentrations of the pollutant $(\mathrm{CV})(\mathrm{mg} / \mathrm{L})$, respectively, $k\left(\mathrm{~min}^{-1}\right)$ is the pseudo-first order rate constant for the pollutant degradation, which is calculated by plotting $\ln \left(C_{0} / C_{t}\right)$ Vs the irradiation time $t$.

The formation of oxidation intermediates may result in the misinterpretation of the experimental data when the degradation of the target pollutant is monitored through UV absorbance measurements, which is not a target analysis. As a matter of fact, the intermediate organic compounds are in turn degraded by the photocatalytic process to a rate which depends on their refractoriness to the treatment process [50]. This behavior can be identified by plotting all the data of the experimental test according to the same kinetic (in this case PFO) and identifying the points of discontinuity (n) and the corresponding PFO kinetics $(n+1)$ [50]. In this case, the points of discontinuity are two, and therefore it is possible to extrapolate three PFO kinetics with different slopes and plot them accordingly (Figure 8).

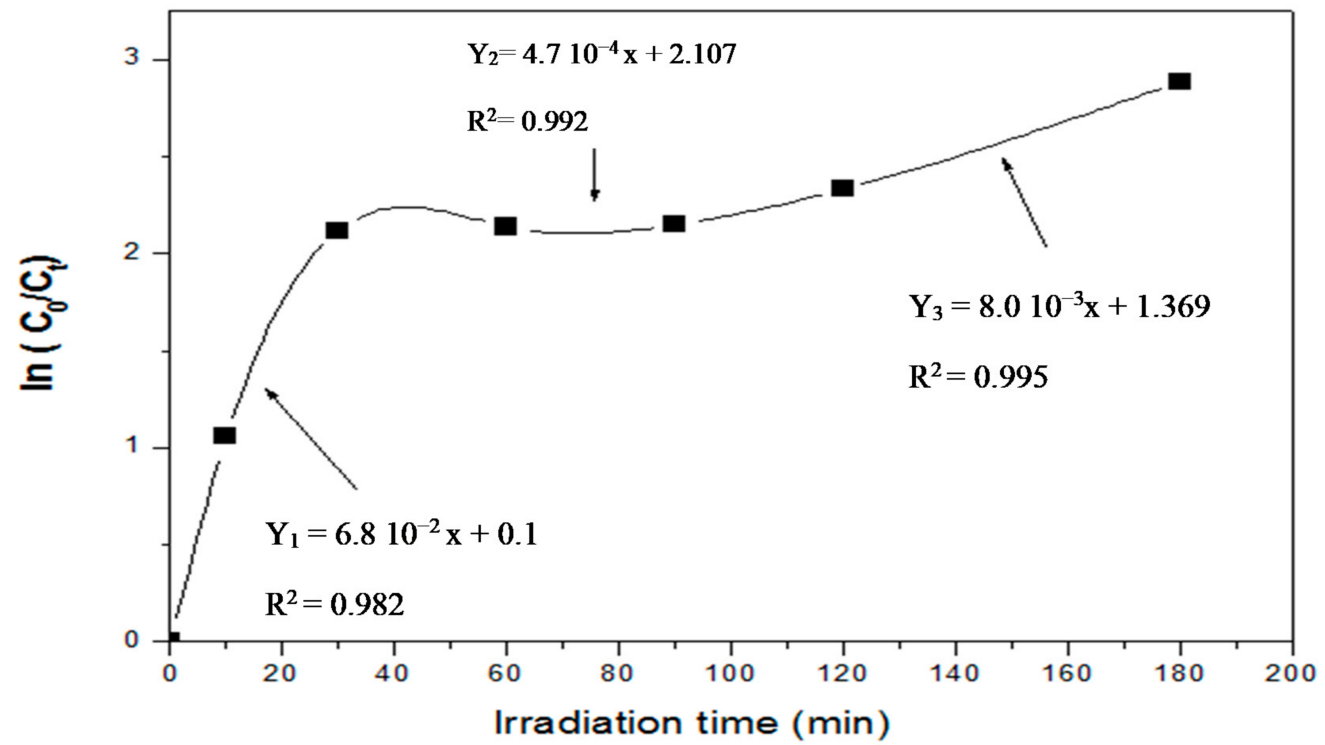

Figure 8. Plot of the pseudo-first-order model of CV dye photocatalytic degradation. 
The corresponding kinetic parameters are given in Table 3. The higher slope of the first kinetic $\left(\mathrm{Y}_{1}\right)$ in the early 30 min can mainly be ascribed to the faster initial degradation of the parent compound (CV). The degradation of more refractory oxidation intermediates may explain the drastically decreased slope of the second kinetic $\left(\mathrm{Y}_{2}\right)$. Finally, the faster kinetic observed in the third step $\left(\mathrm{Y}_{3}\right)$ can be ascribed to the degradation of less refractory, and subsequently formed, oxidation intermediates.

Table 3. The PFO Kinetic parameters of $\mathrm{CV}$ degradation during the heterogeneous photo-Fenton process (conditions: spontaneous $\mathrm{pH}, \mathrm{CV}=10 \mathrm{mg} / \mathrm{L}, \mathrm{H}_{2} \mathrm{O}_{2}=30 \mathrm{mg} / \mathrm{L}$, catalyst concentration $1.0 \mathrm{~g} / \mathrm{L}$ ).

\begin{tabular}{cccc}
\hline PFO Kinetic $\left(\mathbf{Y}_{\mathbf{i}}=\mathbf{a}_{\mathbf{i}} \cdot \mathbf{x}+\mathbf{b}_{\mathbf{i}}\right)$ & $\mathbf{6 . 8} \times \mathbf{1 0}^{-\mathbf{2}} \cdot \mathbf{x} \mathbf{+ 0 . 1}$ & $\mathbf{4 . 7} \times \mathbf{1 0}^{-\mathbf{4}} \cdot \mathbf{x}+\mathbf{2 . 1 0 7}$ & $\mathbf{8 . 0} \times \mathbf{1 0}^{-\mathbf{3}} \cdot \mathbf{x}+\mathbf{1 . 3 6 9}$ \\
\hline $\mathrm{R}_{\mathrm{i}}{ }^{2}$ & 0.982 & 0.992 & 0.995 \\
\hline $\mathrm{k}_{\mathrm{i}}\left(\mathrm{min}^{-1}\right)$ & $2.726 \times 10^{-3}$ & $5.206 \times 10^{-6}$ & 0.0076 \\
\hline $\mathrm{a}_{\mathrm{i}}$ & 0.1498 & 2.10721 & 1.36934 \\
\hline $\mathrm{b}_{\mathrm{i}}$ & 0.06818 & $4.69515 \times 10^{-4}$ & 0.00836 \\
\hline
\end{tabular}

\subsubsection{Characterization of Oxidation Intermediates}

The CV dye demethylated intermediates formed during the photo-Fenton process were detected using LC-MS (Table 4). In addition, an ion chromatography technique was used to detect anionic and cationic by-products of the dye, which were acetate $\left(\mathrm{CH}_{3} \mathrm{COO}-\right)$, formate $\left(\mathrm{HCOO}^{-}\right), \mathrm{Cl}^{-}$, and $\mathrm{NH}_{4}{ }^{+}$. These results are in agreement with previous reports [51,52] and prove the effectiveness of the photo-Fenton process to turn CV dye into less- or non-toxic products [51].

Table 4. Molecular structure, chemical names, and $\mathrm{m} / \mathrm{z}$ values of demethylated intermediates of CV dye detected by LC-MS.

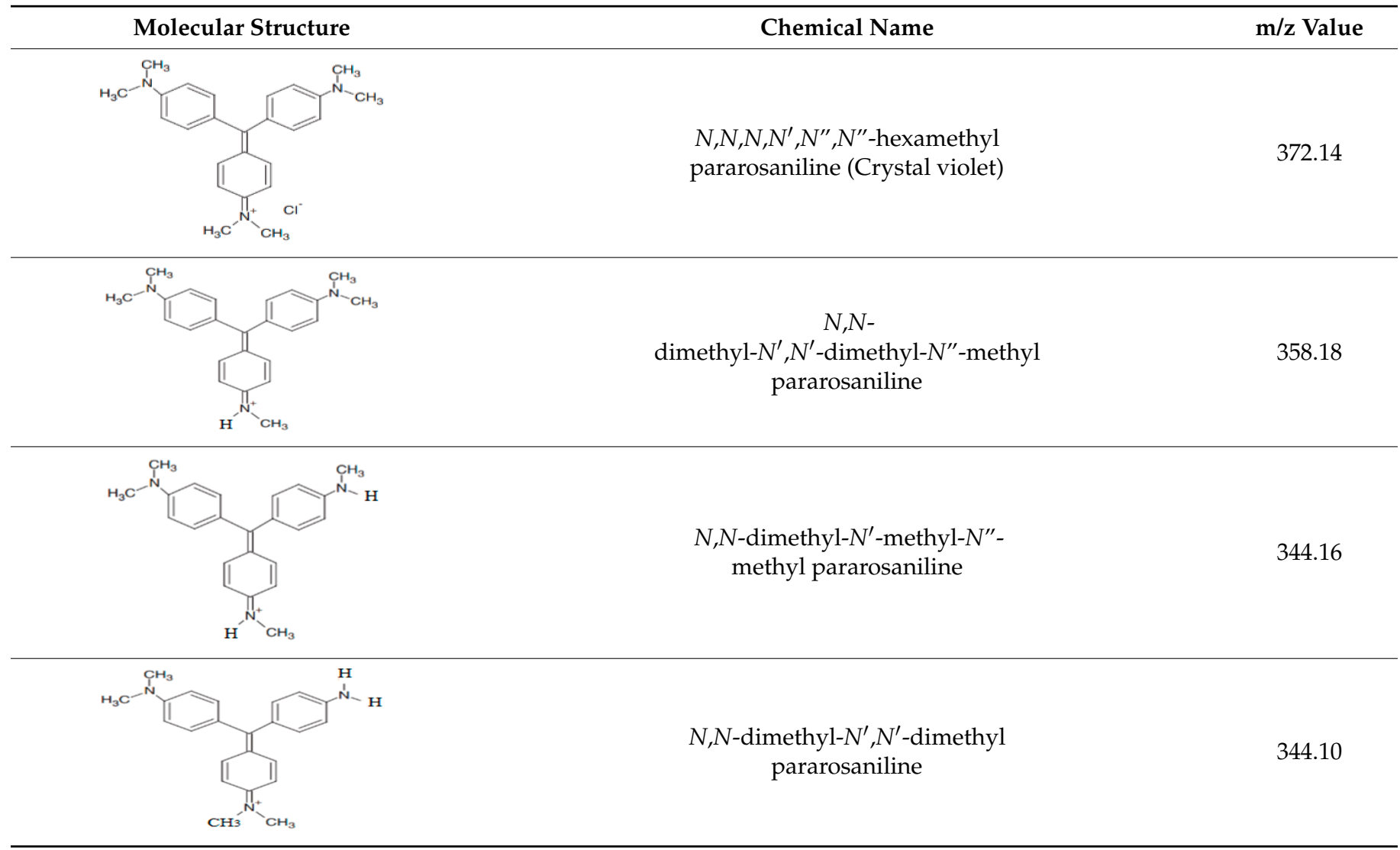


Table 4. Cont.

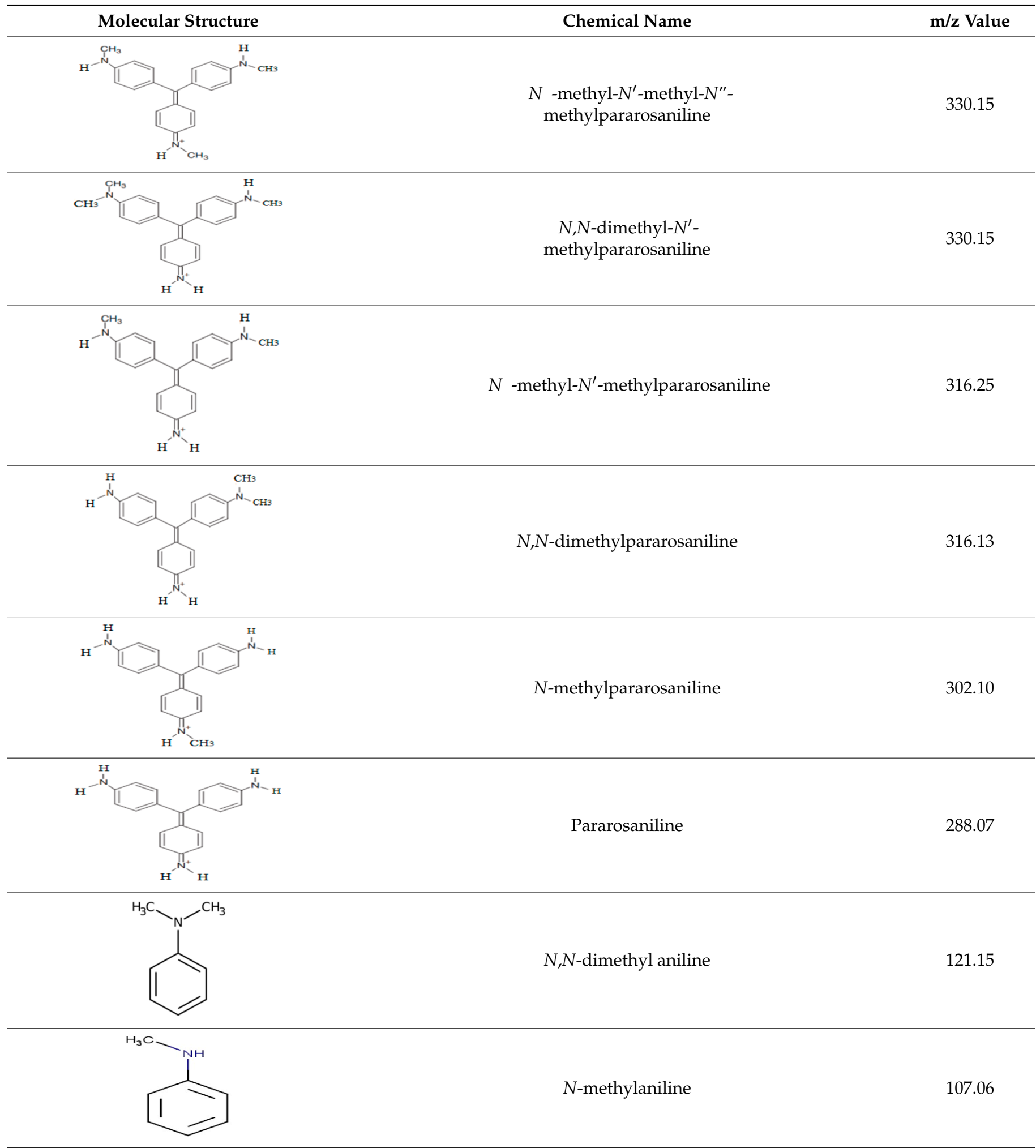

According to the LC/MS and ion chromatography analyses, a mechanism can be proposed for the $\mathrm{CV}$ dye degradation, and this involves two different major pathways: (1) N-demethylation, and (2) cleavage of the chromophore bond structure [52,53]. This is due to the existence of two possible sites in the CV dye molecule for radical attack. During the $\mathrm{N}$-demthylation route, the mono-, di- and tetra-methyl groups in the $\mathrm{CV}$ 
molecules were attacked by ${ }^{\bullet} \mathrm{OH}$ radicals, leading to the production of the following intermediates: $N, N$-dimethyl- $N^{\prime} N^{\prime}$-dimethyl- $N^{\prime \prime}$-methyl pararosaniline, $N, N$-dimethyl- $N^{\prime}$ methyl- $N^{\prime \prime}$-methyl pararosaniline, $N, N$-dimethyl- $N^{\prime}, N^{\prime}$-dimethyl pararosaniline, $N$-methyl$N^{\prime}$-methyl- $N^{\prime \prime}$-methyl pararosaniline, $N, N$-dimethyl- $N^{\prime}$-methyl pararosaniline, $N$-methyl$N^{\prime}$-methyl pararosaniline, $N, N$-dimethyl pararosaniline and $N$-methyl pararosaniline. Then, the further degradation of the pararosaniline compound can lead to shorter chain hydrocarbons and less toxic ions. On the other hand, the cleavage of the CV chromophore ring structure route was marked by the appearance of aliphatic oxidation products, which were $\mathrm{N}, \mathrm{N}$-dimethyl aniline and $\mathrm{N}$-methylaniline compounds. These results are in agreement with earlier findings reported in the literature [51,53,54].

\subsection{Catalyst Regeneration and Stability}

To evaluate the stability of the catalyst, the natural iron oxide employed in the previous tests was recovered and regenerated to check its stability and reusability. The photocatalytic activity of this catalyst was evaluated in three subsequent tests after a regeneration step and the addition of a fresh CV dye solution, under the same operating conditions. No significant reduction in the efficiency of $\mathrm{CV}$ dye adsorption on the catalyst after three regeneration cycles was observed (Figures $9 a$ and 10). The catalyst maintained its adsorptive capacity (70\%) and the CV dye degradation by photo-Fenton decreased from $94 \%$ to $83 \%$ (Figure 9a). Possibly, the reduced efficiency was due to the regeneration method, which did not allow a sufficiently efficient desorption process, making part of the adsorptions sites no longer available for the subsequent photocatalytic treatment tests. Therefore, to improve the regeneration process, either more intensive conditions (e.g., higher temperature) or different methods (e.g., photocatalyst washing with proper chemical desorption solutions) should be used. Furthermore, the morphology of the catalyst after three cycles (Figure 9b) was almost unchanged compared to the initial condition (Figure 2a,b). These results prove that the catalyst is stable and reusable for CV dye degradation.

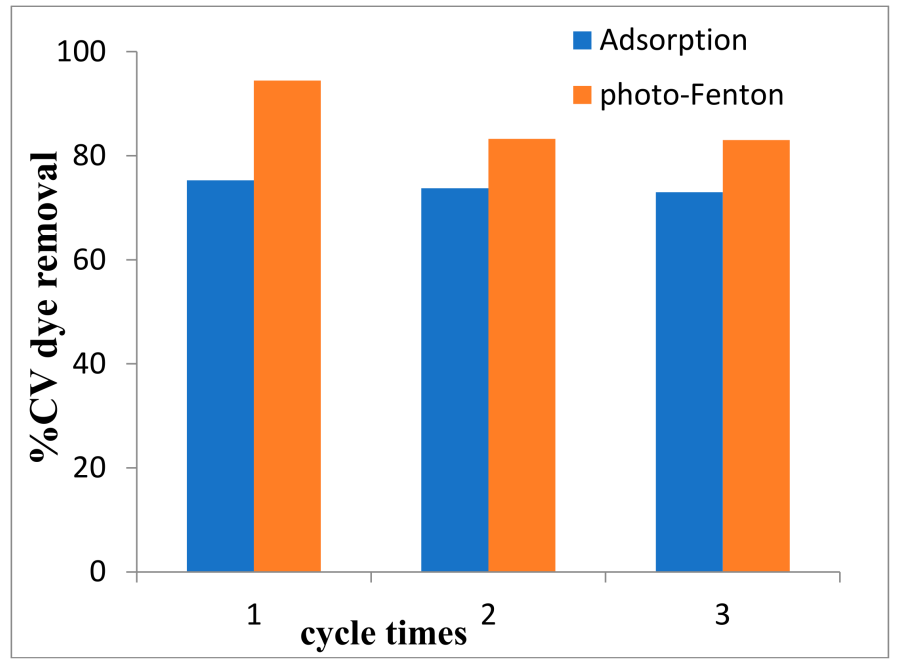

(a)

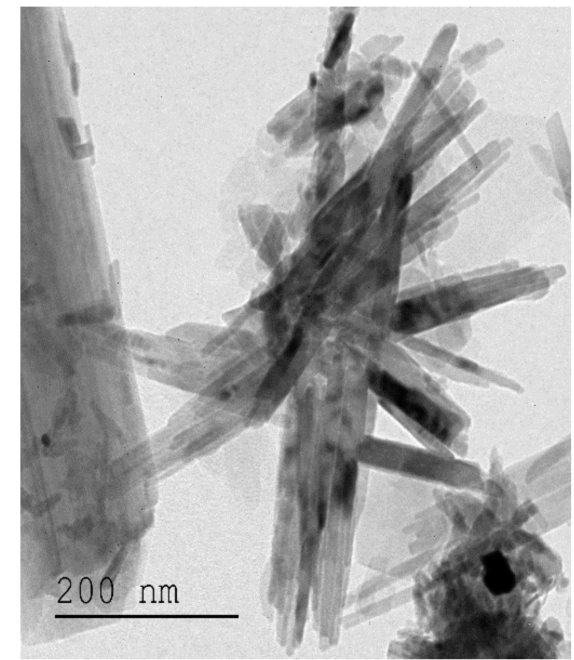

(b)

Figure 9. (a) Removal efficiency of CV dye by natural iron oxide with different cycles; (b) TEM image after three successive cycles.

\subsection{Real Textile Wastewater Treatment}

Real textile wastewater was provided by a textile company in Tunisia, directly after the textile dyeing process and without any kind of treatment. The physico-chemical characteristics of the raw wastewater sample are provided in the Table 5. The investigated wastewater was a mixture of many dyes, such as Novacron Blue 4R (NB4R) and Bezaktiv Red S-Matrix (BRSM) and had a dark green color and maximum absorbance peak at $589 \mathrm{~nm}$ 
(Figure 11). Textile wastewater treatment by photo-Fenton was investigated under different conditions, by increasing the catalyst dose from $1 \mathrm{~g} / \mathrm{L}$ to $10 \mathrm{~g} / \mathrm{L}$ and the $\mathrm{H}_{2} \mathrm{O}_{2}$ concentration from $30 \mathrm{mg} / \mathrm{L}$ to $1 \mathrm{~g} / \mathrm{L}$. Thus, the best option was found to be using $10 \mathrm{~g} / \mathrm{L}$ of catalyst dose and $1.0 \mathrm{~g} / \mathrm{L}$ of $\mathrm{H}_{2} \mathrm{O}_{2}$ at natural $\mathrm{pH}$. As a matter of fact, this condition resulted in decreasing the intensity of the characteristic absorption peak of the raw effluent at $589 \mathrm{~nm}$ (Figure 11), drastically reducing COD, and making the effluent in compliance with standards for industrial wastewater disposal into sewerage (such as the Italian ones) (Table 5).
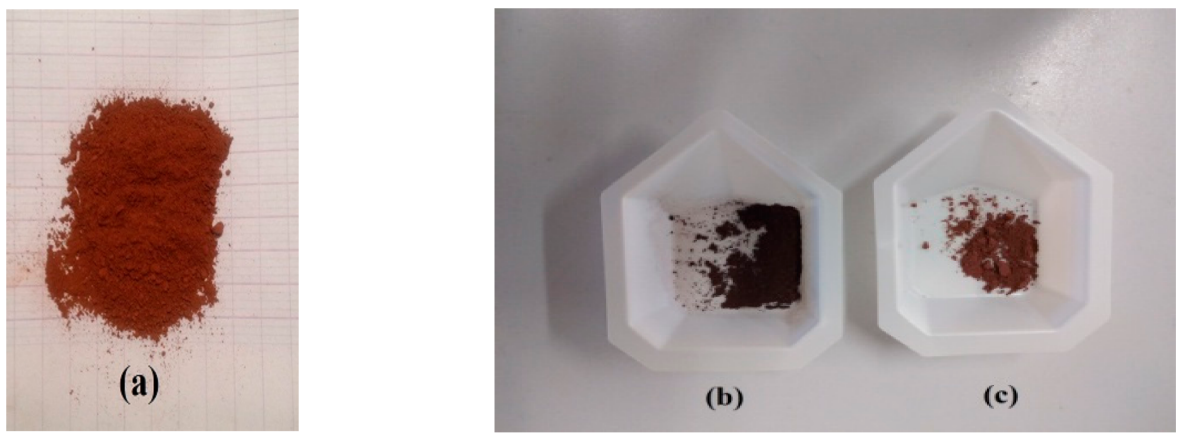

Figure 10. Photograph of (a) fresh catalyst, (b) catalyst after adsorption, (c) catalyst after three regeneration cycles.

Table 5. Main characteristics of the textile effluent before and after the photo-Fenton process, and comparison with Italian standards for industrial wastewater disposal into sewerage (D.Lgs 152/2006).

\begin{tabular}{cccc}
\hline Quality Indicator & Raw Effluent & Treated Effluent & $\begin{array}{c}\text { Italian Standards for Disposal of } \\
\text { Industrial Wastewater into Sewerage }\end{array}$ \\
\hline COD $(\mathrm{mg} / \mathrm{L})$ & 803 & 290 & 500 \\
\hline Turbidity $(\mathrm{NTU})$ & 57 & 25 & - \\
\hline $\mathrm{pH}$ & 9.18 & 8.31 & $5.5-9.5$ \\
\hline $\mathrm{BOD}_{5}(\mathrm{mg} / \mathrm{L})$ & 352 & 149 & 250 \\
\hline Conductivity $(\mu \mathrm{S} / \mathrm{cm})$ & 15.05 & 13.51 & - \\
\hline TSS $(\mathrm{mg} / \mathrm{L})$ & 130 & Traces & 200 \\
\hline
\end{tabular}

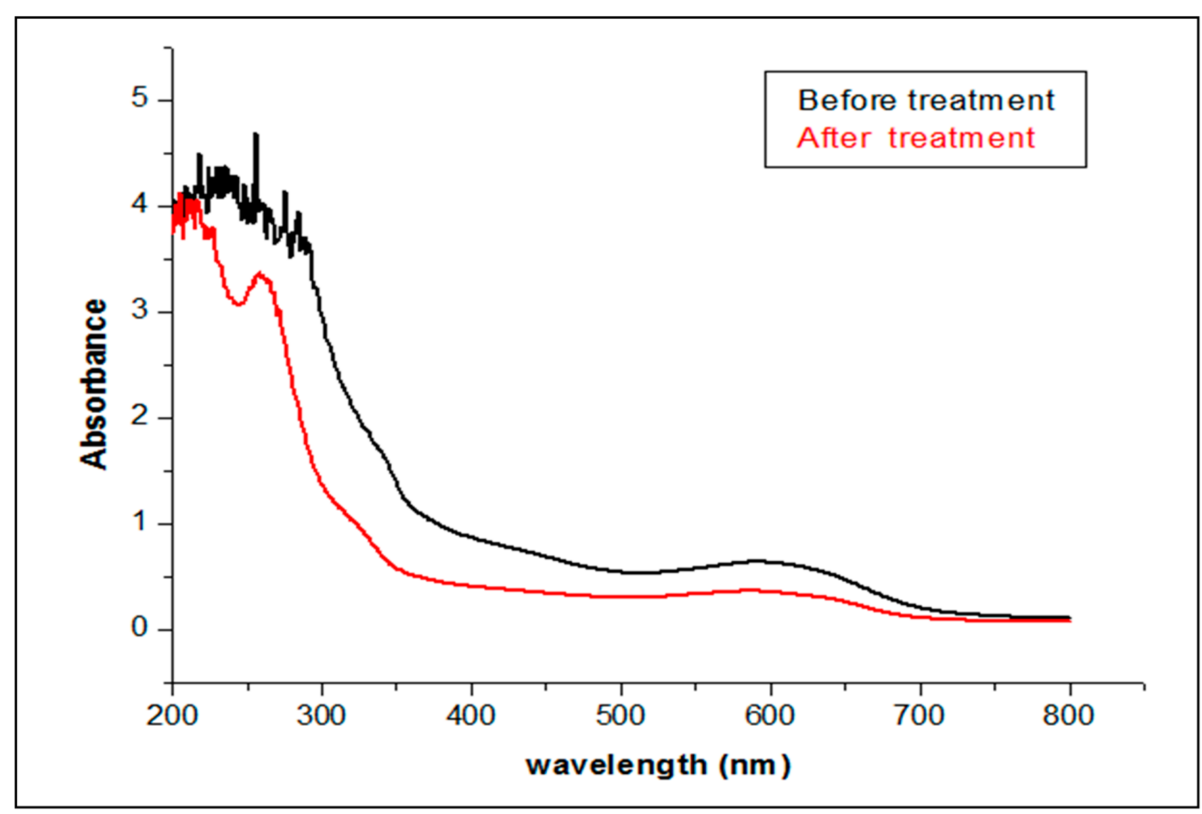

Figure 11. UV-Visible spectra of the real effluent at spontaneous $\mathrm{pH}$ before and after treatment. 


\section{Methods and Materials}

\subsection{Reagents and Chemicals}

$\mathrm{CV}\left(\mathrm{C}_{25} \mathrm{H}_{30} \mathrm{~N}_{3} \mathrm{Cl}\right.$, M.W. $\left.=407.98 \mathrm{~g} \mathrm{~mol}^{-1}\right)$ is a cationic dye (Figure 12a). It is widely used in paint, textile, and biotechnology industry. Its maximum absorption wavelength was experimentally found to be $583 \mathrm{~nm}$ (Figure 12b).

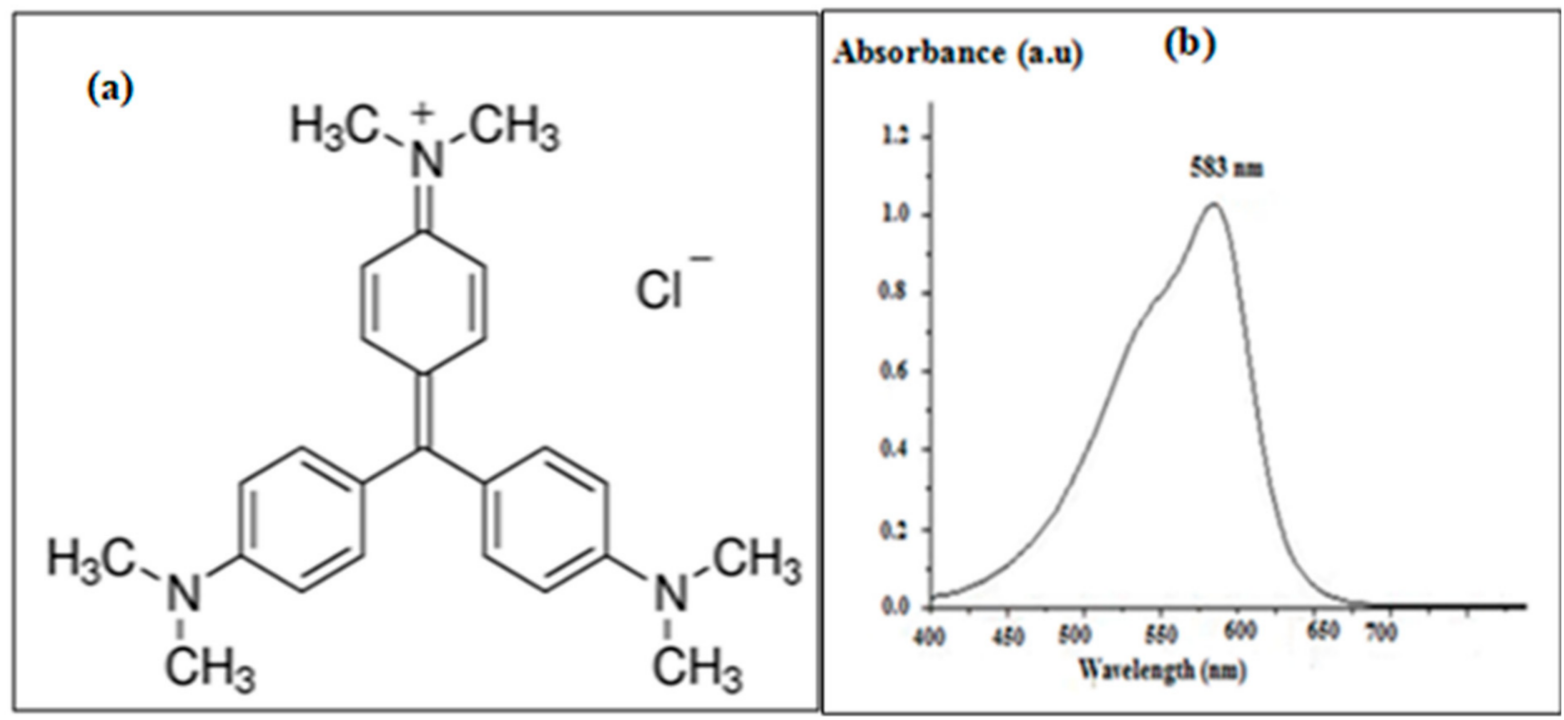

Figure 12. (a) Chemical structure and (b) UV visible spectra of CV dye.

The iron oxide used in this study was a natural material collected from iron-ore deposit located in the Nefza region (North-west Tunisia). The sample was dried and crushed to a small particle size. Chloride salt of $\mathrm{CV}$, hydrogen peroxide (30\% w/v) and titanium (IV) oxysulfate were purchased from Sigma-Aldrich (Germany) and used without any further purification. All the solutions were prepared in Milli-Q water. Reagent-grade ammonium acetate, nitric acid, sodium hydroxide, and HPLC-grade methanol were purchased from Merck. The $\mathrm{pH}$ was adjusted with the addition of proper volumes of $0.1 \mathrm{M} \mathrm{HCl}$ or $0.1 \mathrm{M}$ $\mathrm{NaOH}$ solutions.

\subsection{Characterization of Catalyst}

Different techniques were used to characterize the catalyst. Powder X-ray diffraction was performed using a PANalytical X'Pert HighScore Plus diffractometer, with monochromatic Cu-K radiation source $(\lambda=1.5418 \AA)$ operated at $40 \mathrm{kV}$ and $40 \mathrm{~mA}$. The surface functional groups of the catalyst were investigated by FT-IR technique. The sample was grounded and mixed with $\mathrm{KBr}$ to make a pellet that was analyzed at a wavelength range of $480-4000 \mathrm{~cm}^{-1}$ using a Perkin Elmer infrared spectrophotometer. Raman analysis was performed using a Raman spectrometer (Renishaw brand-inVia Raman) at room temperature, with an excitation laser line set at $632.8 \mathrm{~nm}$ from a He-Ne laser. TEM analysis was performed on a Philips FEI-Tecnai 10 electron microscope operated at $200 \mathrm{kV}$. Quantitative analysis of the elemental composition was identified by EDX. Optical properties were tested by DRS, using a UV-visible spectrophotometer (Shimadzu UV-2700). Isotherm of nitrogen adsorption-desorption of material was measured using a Quantachrome model Nova 1000e surface and porosity analyzer. $\mathrm{S}_{\mathrm{BET}}$ was obtained using the BET method and the total pore volume $\left(V_{t}\right)$ was calculated at a relative $N_{2}$ pressure of $P / P_{0}=0.99$ at liquid nitrogen temperature of $77 \mathrm{~K}$. The $\mathrm{BJH}$ method was employed to determine the mesopore surface area $\left(\mathrm{S}_{\mathrm{BJH}}\right)$, the mesopore volume $\left(\mathrm{V}_{\mathrm{BJH}}\right)$ and the pore size distribution in the mesoporous range $(2-50 \mathrm{~nm})$, based on the desorption data of the isotherm. 


\subsection{Advanced Oxidation and Control Tests}

Different advanced oxidation ( $\mathrm{UV} / \mathrm{H}_{2} \mathrm{O}_{2}$, Fenton and photo-Fenton) and control tests (photolysis, $\mathrm{H}_{2} \mathrm{O}_{2}$ ) were carried out. In photolysis control test, the dye solution was exposed to UVC light for $180 \mathrm{~min}$ and $\mathrm{CV}$ dye concentration was measured every $15 \mathrm{~min}$. For the oxidation process, only $\mathrm{H}_{2} \mathrm{O}_{2}$ was added to the solution and the reaction of $\mathrm{CV}$ dye oxidation was monitored in darkness. $\mathrm{UV} / \mathrm{H}_{2} \mathrm{O}_{2}$ was also studied by exposing the $\mathrm{CV}$ dye solution to UVC light and adding $\mathrm{H}_{2} \mathrm{O}_{2}$.

To evaluate the efficiency of photo-Fenton and Fenton reactions on CV dye degradation, a $200 \mathrm{~mL}$ borosilicate crystallizing dish reactor (shape: round, $\varnothing=90 \mathrm{~mm}$, $\mathrm{h}=45 \mathrm{~mm}$ ) was filled with $\mathrm{CV}$ aqueous solution $(\mathrm{V}=100 \mathrm{~mL})$ and the catalyst dose. The solution was homogenized for $60 \mathrm{~min}$ using a magnetic stirrer in a closed chamber to ensure adsorption-desorption equilibrium at room temperature in dark, then a sample was taken for $\mathrm{CV}$ dye concentration control and centrifuged, filtered and analyzed using a UV-visible spectrophotometer (at $\lambda \max =583 \mathrm{~nm}$ ). In the Fenton test, the time started when $\mathrm{H}_{2} \mathrm{O}_{2}$ was added to the aqueous solution. For photo-Fenton process, the UV-C lamp (16 W, Sankyo Denky G10T5L, Japan), placed at $10 \mathrm{~cm}$ from the top of the aqueous solution, was used as light source and the light intensity $\left(4.9 \mathrm{~mW} / \mathrm{cm}^{2}\right)$ was measured using a radiometer (model HR-2000, Ocean Optics, Florida, USA). In a typical experiment, $0.1 \mathrm{~g}$ of natural iron oxide $\left(\mathrm{m}_{\mathrm{cat}}=0.1 \mathrm{~g}\right)$ was steadily mixed with $100 \mathrm{~mL}$ of $\mathrm{CV}$ dye solution. Then, $3 \mathrm{~mL}$ of suspension was collected every $15 \mathrm{~min}$. The catalyst was removed from the mixed solution by centrifugation ( $9000 \mathrm{rpm}$ for $10 \mathrm{~min}$ ) and subsequently filtered to perform CV spectrophotometric measurements.

In order to perform stability tests, the catalyst was recovered by centrifugation, rinsed with distilled water and dried in an oven at $60^{\circ} \mathrm{C}$ for a period of $24 \mathrm{~h}$. In each experiment, $0.1 \mathrm{~g}$ of catalyst was taken into consideration.

\subsection{Analytical Measurements}

$\mathrm{COD}$ analysis was carried out using cuvette tests ( $\mathrm{HACH} \mathrm{Co}$.). $\mathrm{BOD}_{5}$ was measured according to standard methods (CNR IRSA 5120) [55] using an OXITOP ${ }^{\circledR}$ system [11]. Hydrogen peroxide residual concentration was determined by reaction between Titanium oxysulfate and $\mathrm{H}_{2} \mathrm{O}_{2}$ (DIN $38409 \mathrm{H} 15$ method) to produce pertitanic acid (yellow color). Then, the absorbance measurement of the complex was obtained using a Perkin Elmer UV-vis spectrophotometer at $\lambda=410 \mathrm{~nm}$. Total suspended solids (TSS) were analysed following the CNR IRSA 2090 standard methods [55]. Turbidity values were obtained directly using a 2100AN model turbidity meter (HACH) [56]. Conductivity and $\mathrm{pH}$ were measured using a pH meter edge ${ }^{\circledR}$ (HANNA, model: HI2020-02). The CV residual concentration was analyzed using a Perkin Elmer UV-vis spectrophotometer (Model T60U PG Instruments Ltd.) through absorbance measurement at $\lambda_{\max }=583 \mathrm{~nm}$. To identify the demethylated degradation products of CV dye, an LC/MS system equipped with a binary pump, a photodiode array detector, an autosampler and a micromass detector were used. The used mobile phase was a mixture of methanol and aqueous ammonium acetate buffer $(25 \mathrm{mM})$, with a flow rate of $1.0 \mathrm{~mL} / \mathrm{min}$. Analyses were performed on an Atlantis TM $\mathrm{dC} 18$ column $(250 \mathrm{~mm} \times 4.6 \mathrm{~mm}$ i.d., $\mathrm{dp}=5 \mu \mathrm{m})$ and the column effluent was introduced into the ESI source of the mass spectrometer through a heated nebulizer probe at $350{ }^{\circ} \mathrm{C}$ and with an ion source temperature of $80^{\circ} \mathrm{C}$. The cationic and anionic by-products of the CV dye were analyzed using an Ion-Chromatograph (Metrohm) 800 series (IC), connected to an electrical conductivity detector.

\section{Conclusions}

In this work, natural iron oxide was characterized and used as catalyst in Fenton and photo-Fenton reactions. TEM analysis of the catalyst showed rod shape structures with a mesoporous texture. BET analysis allowed to measure a high specific surface area of the catalyst $\left(45.8 \mathrm{~m}^{2} \mathrm{~g}^{-1}\right)$. According to the optical characterization, the photo catalyst showed absorption in both UV and visible light regions, which makes it a good candidate 
for photo-catalytic processes. The natural iron oxide was evaluated for $\mathrm{CV}$ dye degradation by photo-Fenton reaction and compared to Fenton and $\mathrm{UV} / \mathrm{H}_{2} \mathrm{O}_{2}$ processes, photo-Fenton being the most effective, with almost total degradation of the $\mathrm{CV}$ dye under the optimum conditions $\left(1.0 \mathrm{~g} / \mathrm{L}\right.$ of catalyst dose and $30 \mathrm{mg} / \mathrm{L}$ of $\left.\mathrm{H}_{2} \mathrm{O}_{2}\right)$. Additionally, regeneration experiments proved the stability and reusability of the catalyst. Finally, an application of the process on real textile wastewater revealed promising results in terms of $\mathrm{COD}, \mathrm{BOD}_{5}$ and TSS removals, and made the effluent in compliance with the corresponding standards set by (Italian) regulations for disposal into sewerage.

Author Contributions: S.B.A.: Conceptualization, F.A., S.B.A. and L.R.; methodology, S.B.A.; formal analysis, M.A., S.I.A.-R. and S.B.A.; investigation, S.B.A.; resources, S.I.A.-R., F.A. and L.R.; WritingOriginal Draft, M.A. and S.B.A., Writing-review \& editing, F.A. and L.R.; supervision, F.A. and L.R.; funding acquisition, M.A., S.I.A.-R., S.B.A. and L.R. All authors have read and agreed to the published version of the manuscript.

Funding: The Sirine Ben Ayed scholarship to cover her stay costs in Salerno was funded by the Ministry of Higher Education and Scientific Research (Tunisia). Research activity in Salerno was funded by the University of Salerno through the project entitled "Industrial wastewater treatment by a combination of advanced oxidation and biological processes" (FARB2019, ORSA191152). Formal analysis at King Saud University was funded by King Saud University (Riyadh, Saudi Arabia) through Researchers Supporting Project number (RSP-2020/147).

Acknowledgments: Sirine Ben Ayed wishes to thank Marco De Carluccio and Vincenzo Vaiano for their support during this work. The authors would like to extend their sincere appreciation to King Saud University (Riyadh, Saudi Arabia) for the support of this research through Researchers Supporting Project number (RSP-2021/147).

Conflicts of Interest: The authors declare no conflict of interest.

\section{References}

1. Abukhadra, M.R.; Abukhadra, M.; Rabia, M.; Shaban, M.; Verpoort, F. Heulandite/polyaniline hybrid composite for efficient removal of acidic dye from water; kinetic, equilibrium studies and statistical optimization, optimization. Adv. Powder Tech. 2018, 10, 2501-2511. [CrossRef]

2. Robinson, T.; McMullan, G.; Marchant, R.; Nigam, P. Remediation of dyes in textile effluent: A critical review on current treatment technologies with a proposed alternative. Bioresour. Technol. 2001, 77, 247-255. [CrossRef]

3. Walker, G.M.; Weatherley, L.R. COD removal from textile industry effluent: Pilot plant studies. Chem. Eng. J. 2001, 84, 125-131. [CrossRef]

4. Patel, T.M.; Chheda, H.; Baheti, A.; Patel, P.; Nath, K. Comparative performance of flat sheet and spiral wound modules in the nanofiltration of reactive dye solution. Environ. Sci. Pollut. 2012, 19, 2994-3004. [CrossRef]

5. Zhang, X.; Geng, Z.; Jian, J.; Yiqiang, He.; Zipeng, Lv.; Xinxin, L.; Hongming, Y. Potassium ferrite as heterogeneous photo-fenton catalyst for highly efficient dye degradation. Catalysts 2020, 10, 293. [CrossRef]

6. Lau, W.J.; Ismail, A.F. Polymeric nanofiltration membranes for textile dye wastewater treatment: Preparation, performance evaluation, transport modelling and fouling control. Desalination 2009, 245, 321-348. [CrossRef]

7. Xiong, W.; Zeng, G.; Yang, Z.; Zhou, Y.; Zhang, C.; Cheng, M.; Liu, Y.; Hu, L.; Wan, J.; Zhou, C.; et al. Adsorption of tetracycline antibiotics from aqueous solutions on nanocomposite multi-walled carbon nanotube functionalized MIL-53 (Fe) as new adsorbent. Sci. Total Environ. 2018, 627, 235-244. [CrossRef] [PubMed]

8. Rasalingam, S.; Peng, R.; Koodali, R.T. An insight into the adsorption and photocatalytic degradation of rhodamine B in periodic mesoporous materials. Appl. Catal. B Environ. 2015, 174, 49-59. [CrossRef]

9. Achille, G.N.; Yi-lian, L. Mineralization of organic compounds in wastewater contaminated with petroleum hydrocarbon using Fenton's reagent: A kinetic study. Am. J. Sci. 2010, 6, 58-66.

10. Paździor, K.; Bilińska, L.; Ledakowicz, S. A review of the existing and emerging technologies in the combination of AOPs and biological processes in industrial textile wastewater treatment. Chem. Eng. Sci. 2019, 376, 120597. [CrossRef]

11. De Carluccio, M.; Fiorentino, A.; Rizzo, L. Multi-barrier treatment of mature landfill leachate: Effect of Fenton oxidation and air stripping on activated sludge process and cost analysis. J. Environ. Chem. Eng. 2020, 8, 104444. [CrossRef]

12. Fiorentino, A.; Cucciniello, R.; Di Cesare, A.; Fontaneto, D.; Prete, P.; Rizzo, L.; Corno, G.; Proto, A. Disinfection of urban wastewater by a new photo-Fenton like process using $\mathrm{Cu}$-iminodisuccinic acid complex as catalyst at neutral $\mathrm{pH}$. Water Res. 2018, 146, 206-215. [CrossRef] [PubMed]

13. Arzate, S.; Campos-Mañas, M.C.; Miralles-Cuevas, S.; Agüera, A.; García Sánchez, J.L.; Sánchez Pérez, J.A. Removal of contaminants of emerging concern by continuous flow solar photo-Fenton process at neutral pH in open reactors. J. Environ. Manag. 2020, 261, 110265. [CrossRef] [PubMed] 
14. Papoutsakis, S.; Brites-Nóbrega, F.F.; Pulgarin, C.; Malato, S. Benefits and limitations of using Fe(III)-EDDS for the treatment ofhighly contaminated water at near-neutral pH. J Photochem. Photobiol. A Chem. 2015, 303, 1-7. [CrossRef]

15. ELKhouly, S.M.; Fathy, N.A. Multi-walled carbon nanotubes supported amorphous $\mathrm{Fe}_{2} \mathrm{O}_{3}$ and $\mathrm{Ag}_{2} \mathrm{O}-\mathrm{Fe}_{2} \mathrm{O}_{3}$ as Fenton catalysts for degradation of maxilon red dye. Asia-Pacific. Chem. Eng. Technol. 2018, 13, e2184. [CrossRef]

16. Iervolino, G.; Zammit, I.; Vaiano, V.; Rizzo, L. Limitations and prospects for wastewater treatment by UV and visible-light-active heterogeneous photocatalysis: A critical review. Top. Curr. Chem. 2020, 378, 1-40. [CrossRef]

17. Franco, P.; Sacco, O.; De Marco, I.; Vaiano, V. Zinc oxide nanoparticles obtained by supercritical antisolvent precipitation for the photocatalytic degradation of crystal violet dye. Catalysts 2019, 9, 346. [CrossRef]

18. Mani, S.; Bharagava, R.N. Exposure to crystal violet, its toxic, genotoxic and carcinogenic effects on environment and its degradation and detoxification for environmental safety. Rev. Environ. Contam. Toxicol. 2016, 237, 71-104. [CrossRef] [PubMed]

19. Rizzo, L. Bioassays as a tool for evaluating advanced oxidation processes in water and wastewater treatment. Water Res. 2011, 45, 4311-4340. [CrossRef] [PubMed]

20. Kermani, M.; Mohammadi, F.; Kakavandi, B.; Esrafili, A.; Rostamifasih, Z. Simultaneous catalytic degradation of 2, 4-D and MCPA herbicides using sulfate radical-based heterogeneous oxidation over persulfate activated by natural hematite $\left(\alpha-\mathrm{Fe}_{2} \mathrm{O}_{3} / \mathrm{PS}\right)$. J. Phys. Chem. Solids 2018, 117, 49-59. [CrossRef]

21. Fahlepy, M.R.; Tiwow, V.A. Characterization of magnetite $\left(\mathrm{Fe}_{3} \mathrm{O}_{4}\right)$ minerals from natural iron sand of Bonto Kanang Village Takalar for ink powder (toner) application. J. Phys. Conf. Ser. 2018, 997, 012036. [CrossRef]

22. Jin, W.H.; Cao, G.T.; Sun, J.Y. Hybrid supercapacitor based on $\mathrm{MnO}_{2}$ and columned $\mathrm{FeOOH}$ using $\mathrm{Li}_{2} \mathrm{SO}_{4}$ electrolyte solution. J. Power Sources 2008, 175, 686-691. [CrossRef]

23. Cai, J.; Chen, S.; Ji, M.; Hu, J.; Ma, Y.; Qi, L. Organic additive free synthesis of mesocrystalline hematite nanoplates via two-dimensional oriented attachment. CrystEngComm 2014, 16, 1553-1559. [CrossRef]

24. Sankararamakrishman, N.; Gupta, A.; Viduarthi, S.B. Enhanced arsenic removal at neutral pH using functionalized multiwalled carbon nanotubes. J. Environ. Chem. Eng. 2014, 2, 802-810. [CrossRef]

25. Ben Ayed, S.; Sbihi, H.M.; Azam, M.; Al-Resayes, S.I.; Ayadi, M.T.; Ayadi, F. Local iron ore identification: Comparison to synthesized $\mathrm{Fe}_{3} \mathrm{O}_{4}$ nanoparticles obtained by ultrasonic assisted reverse co-precipitation method for Auramine O dye adsorption. Desalin. Water Treat. 2021, 220, 446-458. [CrossRef]

26. Shenoy, M.R.; Ayyasamy, S.; Reddy, M.V.V.; Kadarkarai, G.; Suryakanth, J.; Tamilarasan, A.; Jeyaramane, C. The effect of morphology-dependent surface charges of iron oxide on the visible light photocatalytic degradation of methylene blue dye. J. Mater. Sci. Mater. Electron. 2020, 31, 17703-17717. [CrossRef]

27. Hanesch, M. Raman spectroscopy of iron oxides and oxy(hydroxides) at lower laser power and possible application in environmental magnetic studies. Geophys. J. Int. 2009, 177, 941-948. [CrossRef]

28. Das, S.; Hendry, M.J. Application of Raman spectroscopy to identify iron minerals commonly found in mine wastes. Chem. Geol. 2011, 290, 101-108. [CrossRef]

29. De Faria, D.L.; Venâncio Silva, S.; De Oliveira, M.T. Raman microspectroscopy of some iron oxides and oxyhydroxides. J. Raman Spectrosc. 1997, 28, 873-878. [CrossRef]

30. De Faria, D.L.A.; Lópes, F.N. Heated goethite and natural hematite: Can Raman spectroscopy be used to differentiate them? Vib. Spectrosc. 2007, 45, 117-121. [CrossRef]

31. Chen, Y.H.; Lin, C.C. Effect of nano-hematite morphology on photocatalytic activity. Phys. Chem. Miner. 2014, 41, 727-736. [CrossRef]

32. Cychosz, K.A.; Thommes, M. Progress in the physisorption characterization of nanoporous gas storage materials. Eng. J. 2018, 4, 559566. [CrossRef]

33. Vu, T.T.; Valdés-Solís, T.; Marbán, G. High surface area stainless steel wire mesh-supported $\mathrm{TiO}_{2}$ prepared by sacrificial template accelerated hydrolysis. A monolithic photocatalyst superior to $\mathrm{P}_{25} \mathrm{TiO}_{2}$. J. Environ. Chem. Eng. 2014, 2, 2229-2235. [CrossRef]

34. Hao, X.Y.; Zhang, Y.Q.; Wang, J.W.; Zhou, W.; Zhang, C.; Liu, S. A novel approach to prepare MCM-41 supported CuO catalyst with high metal loading and dispersion. Microporous Mesoporous Mater. 2006, 88, 38-47. [CrossRef]

35. Păcurariu, C.; Paşka, O.; Ianoş, R.; Muntean, S.G. Effective removal of methylene blue from aqueous solution using a new magnetic iron oxide nanosorbent prepared by combustion synthesis. Clean Technol. Environ. Policy 2016, 18, 705-715. [CrossRef]

36. Alshamsi, F.A.; Albadwawi, A.S.; Alnuaimi, M.M.; Rauf, M.A.; Ashraf, S.S. Comparative efficiencies of the degradation of Crystal Violet using UV/hydrogen peroxide and Fenton's reagent. Dyes Pigm. 2007, 74, 283-287. [CrossRef]

37. Nawaz, S.; Shah, N.S.; Khan, J.A.; Sayed, M.; Al-Muhtaseb, A.; Andersen, H.R.; Muhammad, N.; Murtaza, B.; Khan, H.M. Removal efficiency and economic cost comparison of hydrated electron-mediated reductive pathways for treatment of bromated. Chem. Eng. Sci. 2017, 320, 523-531. [CrossRef]

38. Rizzo, L.; Della Sala, A.; Fiorentino, A.G.; Puma, Li. Disinfection of urban wastewater by solar driven and UV lamp-TiO 2 photocatalysis: Effect on a multi drug resistant Escherichia coli strain. Water Res. 2014, 53, 145-152. [CrossRef]

39. Di Cesare, A.; De Carluccio, M.; Eckert, E.M.; Fontaneto, D.; Fiorentino, A.; Corno, G.; Rizzo, L. Combination of flow cytometry and molecular analysis to monitor the effect of $\mathrm{UVC} / \mathrm{H}_{2} \mathrm{O}_{2}$ vs. $\mathrm{UVC} / \mathrm{H}_{2} \mathrm{O}_{2} / \mathrm{Cu}$-IDS processes on pathogens and antibiotic resistant genes in secondary wastewater effluents. Water Res. 2020, 184, 116194. [CrossRef] [PubMed]

40. Sayed, M.; Hadi, F.; Khan, J.A.; Shah, N.S.; Shah, L.A.; Khan, H.M. Degradation of acetaminophen in aqueous media by $\mathrm{H}_{2} \mathrm{O}_{2}$ assisted gamma irradiation process. Z. Phys. Chem. 2018, 232, 545-558. [CrossRef] 
41. Zhao, L.; Lin, Z.R.; Ma, X.H.; Dong, Y.H. Catalytic activity of different iron oxides: Insight from pollutant degradation and hydroxyl radical formation in heterogene Fenton-like systems. Chem. Eng. J. 2018, 352, 343-351. [CrossRef]

42. Valentine, R.L.; Wang, H.C.A. Iron oxide surface catalyzed oxidation of quinolone by hydrogen peroxide. J. Environ. Eng. 1998, 124, 31-38. [CrossRef]

43. Huang, H.H.; Lu, M.C.; Chen, J.N. Catalytic decomposition of hydrogen peroxide and 2-chlorophenol with iron oxides. Water Res. 2001, 35, 2291-2299. [CrossRef]

44. Garrido-Ramírez, E.G.; Theng, B.K.G.; Mora, M.L. Clays and oxide minerals as catalysts and nanocatalysts in Fenton-like reactions-A review. Appl. Clay Sci. 2010, 47, 182-192. [CrossRef]

45. Lin, S.S.; Gurol, M.D. Catalytic decomposition of hydrogen peroxide on iron oxide: Kinetics, mechanism, and implications. Environ. Sci. Technol. 1998, 32, 1417-1423. [CrossRef]

46. Gao, L.; Zhuang, J.; Nie, L.; Zhang, J.; Zhang, Y.; Gu, N.; Wang, T.; Feng, J.; Yang, D.; Perrett, S.; et al. Intrinsic perox-dase-like activity of ferromagnetic nanoparticles. Nat. Nanotechnol. 2007, 2, 577-583. [CrossRef]

47. Nicell, J.A.; Wright, H. A model of peroxidase activity with inhibition by hydrogen peroxide. Enzym. Microb. Technol. 1997, 21, 302-310. [CrossRef]

48. Guz, L.; Curutchet, G.; Torres Sánchez, R.M.; Candal, R. Adsorption of crystal violet on montmorillonite (or iron modified montmorillonite) followed by degradation through Fenton or photo-Fenton type reactions. J. Environ. Chem. Eng. 2014, 2, 2344-2351. [CrossRef]

49. Ain, Q.U.; Rasheed, U.; Yaseen, M.; Zhang, H.; Tong, Z. Superior dye degradation and adsorption capability of polydopamine modified $\mathrm{Fe}_{3} \mathrm{O}_{4}$-pillared bentonite composite. J. Hazard. Mater. 2020, 397, 122758. [CrossRef]

50. Rizzo, L.; Meric, S.; Kassinos, D.; Guida, M.; Russo, F.; Belgiorno, V. Degradation of diclofenac by TiO 2 photocatalysis: UV absorbance kinetics and process evaluation through a set of toxicity bioassays. Water Res. 2009, 43, 979-988. [CrossRef] [PubMed]

51. Rehman, F.; Sayed, M.; Khan, J.A.; Shah, L.A.; Shah, N.S.; Khan, H.M.; Khattak, R. Degradation of crystal violet dye by Fenton and photo-Fenton oxidation processes. Z. Phys. Chem. 2018, 232, 1771-1786. [CrossRef]

52. Fan, H.J.; Huang, S.T.; Chung, W.H.; Jan, J.L.; Lin, W.Y.; Chen, C.C. Degradation pathways of crystal violet by Fenton and Fentonlike systems: Condition optimization and intermediate separation and identification. J. Hazard. Mater. 2009, 171, 1032-1104. [CrossRef] [PubMed]

53. Chen, C.C.; Chen, W.C.; Chiou, M.R.; Chen, S.W.; Chen, Y.Y.; Fan, H.J. Degradation of crystal violet dye an FeGAC/ $\mathrm{H}_{2} \mathrm{O}_{2}$ process. J. Hazard. Mater. 2011, 196, 420-425. [CrossRef] [PubMed]

54. Fan, H.J.; Lu, C.S.; Lee, W.L.W.; Chiou, M.R.; Chen, C.C. Mechanistic pathways differences between $\mathrm{P}_{25}-\mathrm{TiO}_{2}$ and $\mathrm{Pt}_{-} \mathrm{TiO}{ }_{2}$ mediated CV photodegradation. J. Hazard. Mater. 2011, 185, 227-235. [CrossRef]

55. APAT; IRSA-CNR. Metodi Analitici per le Acque; APAT Manuali e Linee Guida 29/2003; APAT: Rome, Italy, 2003.

56. Rizzo, L.; Agovino, T.; Nahim-Granados, S.; Castro-Alférez, M.; Fernández-Ibáñe, P.; Polo-López, M.I. Tertiary treatment of urban wastewater by solar and UV-C driven advanced oxidation with peracetic acid: Effect on contaminants of emerging concern and antibiotic resistance. Water Res. 2019, 149, 272-281. [CrossRef] [PubMed] 